\title{
As Leguminosae arbóreas das florestas estacionais do Parque Estadual do Itacolomi, Minas Gerais, Brasil
}

\author{
Woody Leguminosae from seasonal forests of Itacolomi State Park, Minas Gerais, Brazil
}

\author{
Laura Cristina Pires Lima ${ }^{1}$, Flávia Cristina Pinto Garcia $^{2}$ \& \\ Ângela Lúcia Bagnatori Sartori ${ }^{3}$
}

\begin{abstract}
Resumo
Este estudo consiste do tratamento taxonômico das Leguminosae arbóreas das florestas estacionais do Parque Estadual do Itacolomi (PEI). As coletas de material botânico ocorreram mensalmente, entre setembro de 2004 e novembro de 2005, ao longo de oito trilhas distribuídas em áreas de florestas estacionais submontana, montana e altimontana. O levantamento resultou em 39 táxons reunidos em 22 gêneros e distribuídos entre as três subfamílias: Caesalpinioideae ( 9 espécies), Mimosoideae (17) e Papilionoideae (13). Os gêneros mais representativos foram Inga (8 espécies), Machaerium (4), Senna e Dalbergia (3, cada), Abarema, Anadenanthera e Tachigali (2, cada). Bauhinia, Cassia, Copaifera, Melanoxylon, Calliandra, Mimosa, Piptadenia, Pseudopiptadenia, Stryphnodendron, Andira, Bowdichia, Ormosia, Platypodium, Pterocarpus e Swartzia apresentaram uma espécie cada. Ormosia friburgensis e Tachigali friburgensis são registradas pela primeira vez para o estado de Minas Gerais. São fornecidos chave de identificação, descrições, ilustrações, dados fenológicos, comentários taxonômicos e preferência por habitats de cada táxon no PEI.

Palavras-chave: Fabaceae, leguminosas, Mata Atlântica, taxonomia.

Abstract

This study presents the taxonomic treatment of woody Leguminosae in seasonal forests of Itacolomi State Park (PEI). Botanical material was collected monthly, from September 2004 to November 2005, along eight trails in submontane, montane and upper montane seasonal forests. Woody Leguminosae were represented by 39 taxa in 22 genera distributed among the three subfamilies: Cesalpinioideae ( 9 species), Mimosoideae (17), and Papilionoideae (13). The most representative genera were Inga (8 species), followed by Machaerium (4), Senna and Dalbergia (3 each), Abarema, Anadenanthera, and Tachigali (2 each). Bauhinia, Cassia, Copaifera, Melanoxylon, Calliandra, Mimosa, Piptadenia, Pseudopiptadenia, Stryphnodendron, Andira, Bowdichia, Ormosia, Platypodium, Pterocarpus, and Swartzia were represented by one species each. Ormosia friburgensis and Tachigali friburgensis are reported for the first time in Minas Gerais state. Analytical key, descriptions, illustrations, data on phenology, and comments on taxonomy and preferred habitat in PEI are provided for all taxa.
\end{abstract}

Keys Word: Fabaceae, legumes, Atlantic forest, taxonomy.

\section{Introdução}

No Brasil, encontram-se cerca de 3.200 espécies nativas de Leguminosae reunidas em 176 gêneros (Giulietti et al. 2005), e distribuídas em quase todas as formações vegetacionais (Barroso et al. 1991). A família tem sido considerada como uma das mais representativas em formações campestres de altitude (Pirani et al. 2003; Dutra et al. 2008a), cerrados (Mendonça et al. 1998) e formações florestais (Oliveira-Filho et al. 1994; Ribeiro 1998; Lima 2000), confirmando sua importância para a flora do Brasil.

No Estado de Minas Gerais, a floresta atlântica ocorre na porção centro-ocidental, principalmente

\footnotetext{
'Universidade Estadual de Feira de Santana, Depto. Biologia, 44031-460, Feira de Santana, BA, Brasil. Autora para correspondência: lcplima@yahoo.com.br ${ }^{2}$ Universidade Federal de Viçosa, Depto. Biologia Vegetal, 36571-000, Minas Gerais, MG, Brasil.

${ }^{3}$ Universidade Federal de Mato Grosso do Sul, Depto. Biologia, Laboratório de Botânica, C.P. 549, 79070-900, Campo Grande, MS, Brasil.
} 
na região da Zona da Mata (Martins 2000) e compreende diferentes formações florestais: ombrófila mista, ombrófila densa e estacional semidecidual; esta última ocupando grande parte do Estado (Silva 2000). Apesar da representatividade destas florestas, os estudos taxonômicos sobre Leguminosae nas florestas estacionais do Estado são escassos e restritos a algumas áreas, como a Estação Biológica de Caratinga (Mendonça-Filho 1996) e o Parque Estadual do Rio Doce (Bortoluzzi et al. 2003, 2004; Bosquetti 2004; Nunes et al. 2007).

O Parque Estadual do Itacolomi (PEI) tem sua vegetação composta por campos rupestres e florestas estacionais; esta última correspondendo a uma expressiva parte da cobertura vegetal. Os estudos botânicos referentes ao PEI consistem em inventários florístico gerais (Peron 1989; Messias et al. 1997) e no tratamento de algumas famílias como Asteraceae (Almeida 2008), Bignoniaceae (Araújo 2008), Bromeliaceae (Coser 2008), Orchidaceae (Alves 1990; Batista et al. 2004) e Polypodiaceae (Rolim \& Salino 2008). As publicações acerca de Leguminosae para o PEI estão concentradas nos campos rupestres (Dutra et al. 2006, 2008b, 2008c, 2009), com apenas o estudo das leguminosas não arbóreas (Lima et al. 2007) para as florestas estacionais.

Este trabalho tem como objetivo apresentar o tratamento taxonômico das espécies arbóreas de Leguminosae das florestas estacionais do PEI, incluindo chave de identificação, descrições e ilustrações das espécies, além de comentários taxonômicos e preferências por habitats.

\section{Material e Métodos}

\section{Área de estudo}

O Parque Estadual do Itacolomi (PEI) foi criado pelo decreto $n^{\circ} 4465$ de 19 de junho de 1967, e está localizado entre os meridianos $43^{\circ} 32^{\prime}$ e $43^{\circ} 22^{\prime} \mathrm{W}$ e os paralelos $20^{\circ} 30^{\prime}$ e $20^{\circ} 20^{\prime} \mathrm{S}$, nos municípios de Ouro Preto e Mariana (Messias et al. 1997). A vegetação do PEI é composta por campos rupestres e florestas. A classificação adotada neste trabalho para as florestas estacionais está baseada em Oliveira-Filho \& Fontes (2000), que as dividem em submontana (300-700 m de altitude), montana (700$1100 \mathrm{~m}$ ) e altimontana (acima de $1100 \mathrm{~m}$ ). O clima regional é de altitude, relativamente úmido, com temperatura média de $21^{\circ} \mathrm{C}$, máxima de $33^{\circ} \mathrm{C}$ e mínima de $4^{\circ} \mathrm{C}$, pluviosidade estimada em $2.000 \mathrm{~mm}$ anuais e concentração de chuvas de outubro a março (Messias et al. 1997).

\section{Coleta e tratamento taxonômico do material botânico}

Foram realizadas coletas mensais de setembro de 2004 a novembro de 2005, em áreas de florestas estacionais submontana, montana e altimontana, ao longo de oito trilhas (Lima et al. 2007): 1. Alcan; 2. Estrada de Baixo; 3. Forno; 4. Estrada da Torre; 5. Baú; 6. Custódio; 7. Belém; 8. Cibrão. Nesta última trilha, as espécies foram coletadas ao longo do rio Mainarte. O material coletado foi depositado no herbário VIC, do Departamento de Biologia Vegetal da Universidade Federal de Viçosa, com duplicatas enviadas para o herbário OUPR, da Universidade Federal de Ouro Preto.

A identificação das espécies foi realizada com base na literatura taxonômica, comparação com coleções dos herbários (BHCB, OUPR, VIC) e consulta a especialistas. A classificação adotada segue Lewis et al. (2005) e a terminologia para as descrições morfológicas está de acordo com Radford et al. (1974), Harris \& Harris (1994) e Barroso et al. (1999). As descrições das espécies estão padronizadas por subfamílias, incluindo a amplitude morfológica do material examinado, complementada com a do material adicional quando necessário. As ilustrações foram confeccionadas com base em material herborizado e/ou conservado em álcool 70\%, com auxílio de estereomicroscópio Olympus, incluindo características vegetativas e reprodutivas importantes para a identificação das espécies. Os dados fenológicos de floração e frutificação foram baseados no acompanhamento mensal ao longo das oito trilhas amostradas do PEI.

\section{Resultados}

O estudo taxonômico das espécies arbóreas de Leguminosae ocorrentes nas florestas estacionais do PEI totalizou 39 táxons reunidos em 22 gêneros: Caesalpinioideae (9 espécies), Mimosoideae (17) e Papilionoideae (13). Os gêneros mais representativos foram Inga (8 espécies), Machaerium (4), Senna e Dalbergia (3), Abarema, Anadenanthera e Tachigali (2); os demais gêneros (Bauhinia, Cassia, Copaifera, Melanoxylon, Calliandra, Mimosa, Piptadenia, Pseudopiptadenia, Stryphnodendron, Andira, Bowdichia, Ormosia, Platypodium, Pterocarpus e Swartzia) apresentaram apenas uma espécie na área. Ormosia friburgensis e Tachigali friburgensis foram registradas pela primeira vez em Minas Gerais. 


\section{Tratamento Taxonômico \\ Chave para identificação das Leguminosae arbóreas das florestas estacionais do Parque Estadual do Itacolomi}

1. Folhas unifolioladas

1. Bauhinia longifolia

1'. Folhas plurifolioladas.

2. Folhas pinadas.

3. Nectários foliares presentes.

4. Raque foliar marginada ou alada; corola gamopétala, actinomorfa; androceu monadelfo; estaminódios ausentes; sementes com sarcotesta. Inga

5. Folhas (14)16-28-folioladas; folíolos até 2,5 cm compr. 19. I. schinifolia

5'. Folhas 4-12-folioladas; folíolos acima de 6,2 cm compr.

6. Raque foliar marginada; estípulas oblanceoladas

15. I. cylindrica

6'. Raque foliar alada; estípulas lineares, ovadas ou ovado-lanceoladas.

7. Folhas 4-folioladas, folíolos de face abaxial glabra ou puberulenta .........

18. I. marginata

7'. Folhas 6-12-folioladas, folíolos de face abaxial tomentosa ou hirsuta.

8. Nectários foliares estipitados; filetes róseos ........... 22. I. vulpina

8'. Nectários foliares sésseis; filetes alvos ou cremes.

9. Estípulas lineares; nectários foliares transversalmente comprimidos 16. I. edulis

9'. Estípulas ovadas ou ovado-lanceoladas; nectários foliares circulares ou triangulares.

10. Ramos velutinos; folhas 12-folioladas; legumes nucóides recurvados, plano-compressos.....

20. I. sessilis

10'. Ramos tomentosos; folhas 8-10-folioladas; legumes nucóides retos, cilíndricos.

11. Corola lanosa; estames até 42 ; frutos acima $12,5 \mathrm{~cm}$ compr.

17. I. ingoides

11'. Corola serícea; estames acima de 100; frutos até 10 cm compr. 21. I. vera subsp. affinis

4'. Raque foliar não marginada nem alada; corola dialipétala, zigomorfa; androceu dialistêmone; estaminódios presentes; sementes sem sarcotesta Senna

12. Folhas (32)44-48-folioladas; raque foliar acima de $10 \mathrm{~cm}$ compr.; folíolos até $3,8 \mathrm{~cm}$ compr.; nectários foliares somente entre o $1^{\circ}$ par de folíolos

6. S. multijuga subsp. lindleyana

12'. Folhas 4-6-folioladas; raque foliar até $5 \mathrm{~cm}$ compr.; folíolos acima de 6,7 cm compr.; nectários foliares entre todos os pares de folíolos.

13. Estípulas reniformes; inflorescências racemosas; sépalas oblongas; pétala centro-adaxial obovada; frutos plano-compressos

7. S. reniformis

13'. Estípulas lineares; inflorescências paniculadas; sépalas ovadas; pétala centroadaxial orbicular; frutos cilíndricos 5. S. macranthera var. nervosa

3'. Nectários foliares ausentes.

14. Folhas paripinadas.

15. Folhas 32-36-folioladas; corola levemente zigomorfa; lomentos drupáceos

2. Cassia ferruginea var. ferruginea

15'. Folhas 10-16-folioladas; corola actinomorfa; criptossâmaras. Tachigali

16. Raque foliar cilíndrica, folíolos de face abaxial áureo-tomentosa, nervuras terciárias conspícuas

9. T. rugosa

16'. Raque foliar triangular, folíolos de face abaxial alvo-pubescente, nervuras terciárias inconspícuas 8. T. friburgensis

14'. Folhas imparipinadas.

17. Folíolos predominantemente opostos. 
18. Estipelas presentes.

19. Folhas 5-7-folioladas, raque marginada; face adaxial dos folíolos tomentosa; corola ausente, estames acima de 27, dialistêmones 39. Swartzia pilulifera

19'. Folhas 13-folioladas, raque não marginada; face adaxial dos folíolos glabra; corola presente; estames 10, diadelfos 27. Andira fraxinifolia

18. Estipelas ausentes.

20. Folhas 7-9-folioladas, face abaxial dos folíolos pubescente; legumes; semente unicolor 36. Ormosia friburgensis

20'. Folhas 17-21-folioladas; face abaxial dos folíolos glabra; criptolomentos; semente bicolor 4. Melanoxylon brauna

17’. Folíolos predominantemente alternos.

21. Venação dos folíolos reticulada; corola ausente; semente com arilo ... 3. Copaifera reticulata

21'. Venação dos folíolos broquidódroma, craspedódroma ou camptódroma; corola presente; semente sem arilo.

22. Ramos armados Machaerium

23. Folhas 13-21-folioladas; venação dos folíolos broquidódroma; sâmaras glabras ...

34. M. nyctitans

23'. Folhas (29-)37-45-folioladas; venação dos folíolos craspedódroma; sâmaras pubescentes

33. M. hirtum

22'. Ramos inermes.

24. Folíolos com venação camptódroma; frutos com região seminífera apical

37. Platypodium elegans

24'. Folíolos com venação broquidódroma; frutos com região seminífera basal ou central. 25. Folhas 5-7-folioladas.

26. Folíolos de margem revoluta; sâmaras elípticas ou oblongas

30. Dalbergia revoluta

26'. Folíolos de margem não revoluta; sâmaras orbiculares

38. Pterocarpus rohrii

25'. Folhas 9-23-folioladas.

27. Ápice dos folíolos agudo ou acuminado

Machaerium

28. Ramos pubescentes ou tomentosos; folhas 9-11 folioladas; folíolos de ápice acuminado; sâmaras falciformes 32. M. brasiliense

28'. Ramos glabrescentes ou vilosos; folhas 15-23-folioladas; folíolos de ápice agudo; sâmaras oblongas

35. M. villosum

27'. Ápice dos folíolos retuso ou obtuso.

29. Folíolos acima $4 \mathrm{~cm}$ compr.; corola azul; legumes samaróides 28. Bowdichia virgilioides

29’. Folíolos até $2,5 \mathrm{~cm}$ compr.; corola branca; sâmaras com região seminífera central Dalbergia

30. Folíolos oblongos; cálice pubescente; estandarte glabro 29. D. nigra

30’. Folíolos elípticos ou obovados; cálice viloso; estandarte tomentoso

31. D. villosa var. vilosa

2'. Folhas bipinadas.

31. Nectários foliares ausentes.

32. Ramos estriados, escabros; flor tetrâmera; craspédios muricados ........ 23. Mimosa scabrella

32'. Ramos cilíndricos, glabros ou glabrescentes; flor pentâmera ou hexâmera; legumes glabros ou puberulentos 14. Calliandra parvifolia

31'. Nectários foliares presentes.

33. Ramos armados; corola dialipétala

24. Piptadenia gonoacantha

33'. Ramos inermes; corola gamopétala.

34. Pinas até 10 pares; androceu monadelfo; frutos circinados; semente bicolor .... Abarema 
35. Foliólulos oblongo-subfalcados; inflorescências racemosas, homomórficas .....

10. A. langsdorffii

35'. Foliólulos ovado-rômbico; inflorescências umbeliformes, heteromórficas 11. A. obovata

34'. Pinas acima de 12 pares; androceu dialistêmone; frutos retos ou contorcidos; semente unicolor.

36. Foliólulos alternos; filetes vináceos; frutos tipo legume nucóide.. 26. Stryphnodendron polyphyllum

36'. Foliólulos opostos ou subopostos; filetes alvos; frutos tipo folículo.

37. Foliólulos acima de $4 \mathrm{~mm}$ compr., nectários globosos

12. Anadenanthera colubrina var. colubrina

37'. Foliólulos até 3,2 mm compr., nectários pateliformes.

38. Nectários foliares arredondados; inflorescências espiciformes; folículos contorcidos, margem não constricta entre as sementes

25. Pseudopiptadenia contorta

38'. Nectários foliares oblongos; inflorescências capituliformes; folículos não contorcidos, margem contricta entre as sementes .

13. Anadenanthera peregrina

\section{Caesalpinioideae}

1. Bauhinia longifolia (Bong.) Steud., Nomencl. bot. (ed. 2) 2(1): 191. 1840.

Fig. 1 a

Árvores 8-10 m alt., ramos cilíndricos, glabrescentes. Estípulas ca. 2 mm compr., lineares, caducas; pecíolo 2-3 cm compr.; raque ausente; nectários intra-estipulares, tubulares. Folhas unifolioladas, bilobadas; folíolos $8-9 \times 7-8,5 \mathrm{~cm}$, lobos 2,5-4×2-3,3 cm, ápice agudo ou obtuso, base truncada ou obtusa, face adaxial glabra, face abaxial adpresso-pubescente, 7-9 nervados. Inflorescências pseudo-racemosas, terminais; pedúnculo ca. $9 \mathrm{~mm}$ compr., puberulento; raque 3-5 cm compr., puberulenta. Flores pentâmeras, zigomorfas, pediceladas; cálice 1,7-3 cm compr., gamossépalo, tubuloso, puberulento externamente; corola ca. $4,5 \mathrm{~cm}$ compr., esverdeada, pétala centro-adaxial linear; estames 10, heterodínamos, monadelfos, porção livre dos filetes 2-3,8 cm compr., glabros, anteras ca. $1,1 \mathrm{~cm}$ compr., estaminódios 2; ovário ca. $1 \mathrm{~cm}$ compr., tomentoso, estípite ca. $4 \mathrm{~mm}$ compr.; estilete ca. $4 \mathrm{~cm}$ compr., curvado, glabro; estigma terminal, glabro. Legumes, $15-16 \times 1,1 \mathrm{~cm}$, plano-compressos, pubescentes; sementes 11-14, ca. $1 \times 0,6 \mathrm{~cm}$, obovadas, castanho-escuras.

Material examinado: Mariana, Cibrão, 30.III.2005, fl., L.C.P. Lima et al. 319 (VIC).

Material adicional: Viçosa, campus da Universidade Federal de Viçosa, 10.IV.1982, fr., F.A. Silveira s.n. (VIC 7658).

Diferencia-se das demais Leguminosae arbóreas do PEI pelas folhas unifolioladas bilobadas e os nectários intra-estipulares. No material examinado, observou-se que folíolos jovens tendem a ser inteiros. No PEI, foi encontrada em floresta estacional submontana, floresceu de março a maio, mas não frutificou no período de estudo.
2. Cassia ferruginea var. ferruginea (Schrad.) Schrad. ex DC., Prodr. 2: 489. $1825 . \quad$ Fig. 1 b-d Árvores 4-12 m alt., ramos cilíndricos, tomentosos. Estípulas ca. $9 \mathrm{~mm}$ compr., linearlanceoladas, caducas; pecíolo 1,4-2,2 cm compr.; raque $15-18 \mathrm{~cm}$ compr., canaliculada; nectários ausentes. Folhas 32-36-folioladas, paripinadas; folíolos 2,7-3 ×0,9-1 cm, opostos, subopostos ou alternos, oblongos, base obtusa ou assimétrica, ápice obtuso ou mucronado, face adaxial pubérula, face abaxial pubescente, principalmente na nervura principal. Inflorescências racemosas, axilares; pedúnculo ca. $1 \mathrm{~cm}$ compr., ferrugíneo-tomentoso; raque 16-19 cm compr., ferrugíneo-tomentosa. Flores pentâmeras, levemente zigomorfas, pediceladas; cálice ca. $9 \mathrm{~mm}$ compr., dialissépalo, sépalas ovadas, glabras externamente; corola ca. $2,5 \mathrm{~cm}$ compr., amarela, pétala centro adaxial oblanceolada; estames 7, heterodínamos, dialistêmones, em dois verticilos, 4 medianos e 3 abaxiais maiores, filetes sigmóides, filetes 7-30 mm compr., glabros, anteras ca. $3 \mathrm{~mm}$ compr., estaminódios 3; ovário ca. $2 \mathrm{~cm}$ compr., tomentoso, estípite ca. $3 \mathrm{~mm}$ compr.; estilete ca. $1 \mathrm{~mm}$ compr., curvado, tomentoso; estigma terminal, ciliado. Lomentos drupáceos, 36-54×1,8-2 cm, cilíndricos, glabros; sementes 74-98, ca. $9 \times 6 \mathrm{~mm}$, arredondadas, castanhas.

Material examinado: Mariana, estrada do Cibrão, 30.III.2005, fr., L.C.P. Lima et al. 323 (VIC); 18.X.2005, fl., L.C.P. Lima et al. 392 (VIC).

Caracteriza-se pelo número de folíolos (3236) e o fruto do tipo lomento drupáceo. No PEI, foi coletada em floresta estacional submontana, floresceu de outubro a novembro e frutificou de fevereiro a agosto. 

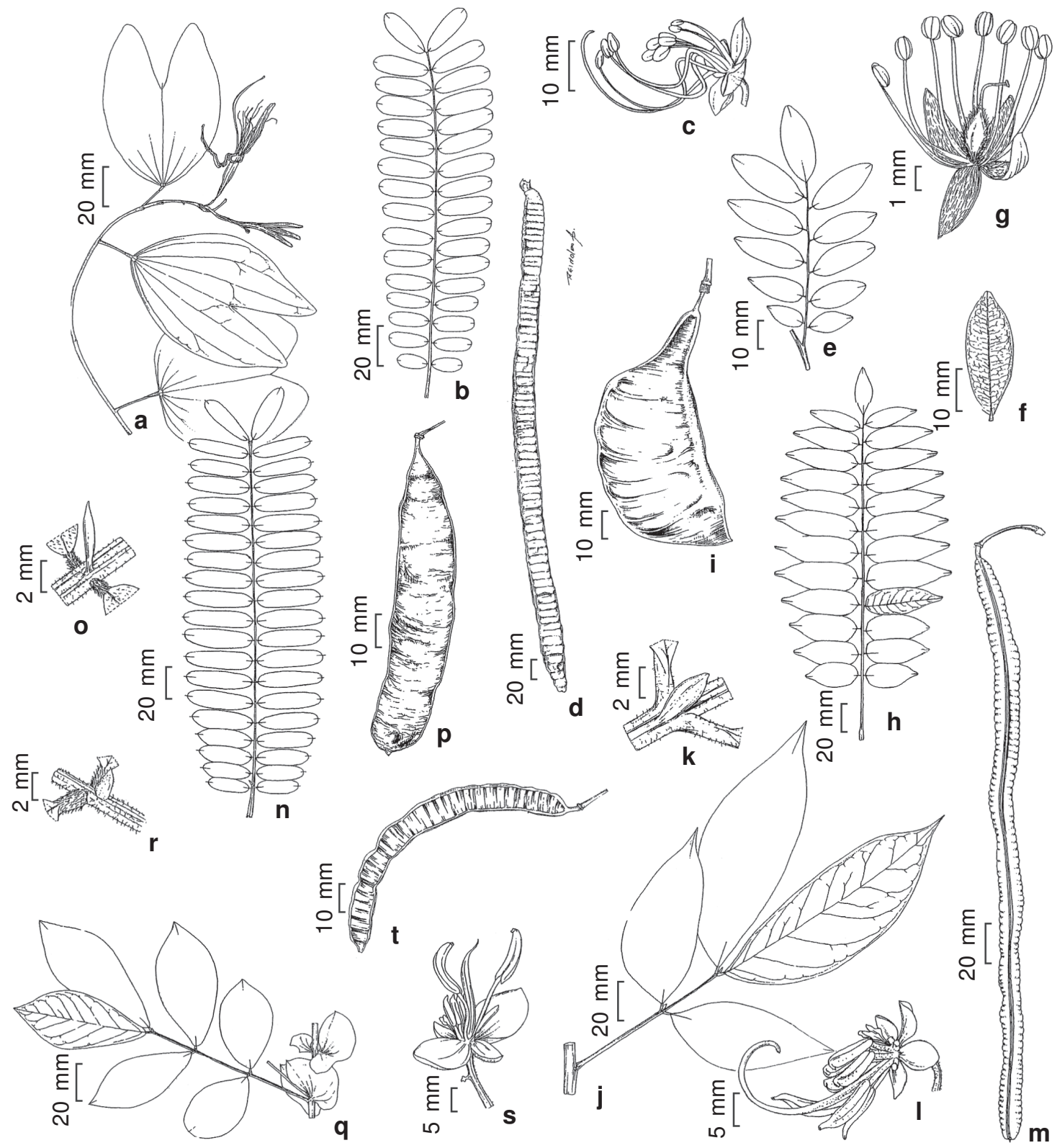

Figura 1 - a. Bauhinia longifolia (Lima 319) - a. ramo com inflorescência. b-d. Cassia ferruginea var. ferruginea (b-c Lima 323; d Lima 392) - b. folha; c. flor sem pétalas; d. fruto. e-g. Copaifera reticulata (Lima 239) - e. folha; f. face abaxial do folíolo; g. flor. h-i. Melanoylon brauna (Lima 364) - h. folha; i. fruto. j-m. Senna macranthera var. nervosa (j-1 Lima 292; m Lima 350) - j. folha; k. nectário; 1. flor sem pétalas; m. fruto. n-p. Senna multijuga subsp. lindleyana (Lima 394) -n. folha; o. nectário; p. fruto. q-t. Senna reniformis (q-r, t Lima 333; s Lima 232) - q. folha; r. nectário; s. flor sem pétalas; t. fruto.

Figure 1 - a. Bauhinia longifolia (Lima 319) - a. flowering branch. b-d. Cassia ferruginea var. ferruginea (b-c Lima 323; d Lima 392) - b. leaf; c. flower without petals; d. fruit. e-g. Copaifera reticulata (Lima 239) - e. leaf; f. abaxial surface of leaflet; g. flower. h-i. Melanoylon brauna (Lima 364) - h. leaf; i. fruit. j-m. Senna macranthera var. nervosa (j-1 Lima 292; m Lima 350) - j. leaf; k. nectary; 1. flower without petals; m. fruit. n-p. Senna multijuga subsp. lindleyana (Lima 394) - n. leaf; o. nectary; p. fruit. q-t. Senna reniformis (q-r, t Lima 333; s Lima 232)- q. leaf; r. nectary; s. flower without petals; t. fruit. 
3. Copaifera reticulata Ducke, Arch. Jard. Bot. Rio de Janeiro 1: 22. 1915.

Fig. 1 e-g

Árvores 5-8 m alt., ramos cilíndricos, tomentosos. Estípulas não observadas, caducas; pecíolo 0,91,2 cm compr.; raque 4-6 cm compr., canaliculada; nectários ausentes. Folhas 7-11-folioladas, imparipinadas; folíolos 2,5-3(-4,5) ×1-1,5(-1,7) cm, alternos, ovado-lanceolados ou elípticos, base aguda ou obtusa, ápice retuso, obtuso ou agudo, face adaxial glabra, face abaxial tomentosa na nervura principal, venação reticulada. Inflorescências em panícula de espigas, axilares; pedúnculo 1,5-2 cm compr., tomentoso; raque 4-5 $\mathrm{cm}$ compr., tomentosa. Flores tetrâmeras, apétalas, sésseis; cálice ca. $9 \mathrm{~mm}$ compr., dialissépalo, sépalas ovadas, glabras externamente; corola ausente; estames 8, homodínamos, dialistêmones, filetes ca. 5 mm compr., glabros, anteras ca. $1 \mathrm{~mm}$ compr., estaminódios ausentes; ovário séssil ca. $2 \mathrm{~mm}$ compr., barbado; estilete ca. $3 \mathrm{~mm}$ compr., curvado, glabro; estigma terminal, glabro. Legumes, 2-3×1,5-1,8 cm, túrgidos, glabros; semente 1 , ca. $1,8 \times 1,2 \mathrm{~cm}$, arredondada, enegrecida, arilo amarelado ou alaranjado.

Material selecionado: Mariana, estrada do Cibrão, 7.XII.2004, fl., L.C.P. Lima \& M.E.F. Araújo 239 (VIC); trilha de Belém, 21.I.2005, fl. e fr., L.C.P. Lima et al. 275 (VIC).

Pode ser reconhecida por apresentar folíolos alternos, flores tetrâmeras e sementes enegrecidas com arilo amarelado ou alaranjado; o comprimento do pecíolo foi menor que o descrito por Dwyer (1951). No PEI, ocorre em florestas estacionais submontana, montana e altimontana, tendo florescido de dezembro a janeiro e frutificado de maio a setembro.

4. Melanoxylon brauna Schott, Sist. veg. 4: 406. 1827.

Fig. 1 h-i

Árvores 18-20 m alt., ramos cilíndricos, tomentosos. Estípulas não observadas, caducas; pecíolo 4,5-5,5 cm compr.; raque 16-18 cm compr., estriada; nectários ausentes. Folhas 17-21-folioladas, imparipinadas; folíolos 4,5-6,5×1,5-2 cm, opostos, subopostos ou raramente alternos, elípticos, base obtusa, ápice agudo, ambas as faces glabras. Inflorescências paniculadas, terminais; pedúnculo ca. $3 \mathrm{~cm}$ compr., ferrugíneo-tomentoso; raque ca. $6 \mathrm{~cm}$ compr., ferrugíneo-tomentosa. Flores pentâmeras, actinomorfas, pediceladas; cálice ca. 1,2 cm compr., dialissépalo, sépalas obovadas, ferrugíneo-tomentosas externamente; corola ca. $2,3 \mathrm{~cm}$, amarela, pétalas orbiculares; estames 10, heterodínamos, dialistêmones, filetes ca. 1,6 cm compr., ferrugíneo-vilosos, anteras ca. 3 mm compr., estaminódios ausentes; ovário ca. $9 \mathrm{~mm}$ compr., ferrugíneo-viloso, estípite ca. $2 \mathrm{~mm}$ compr.; estilete ca. 3 mm compr., curvado, glabro; estigma terminal, ciliado. Criptolomentos, 6,7-11× 3,5-3,8 cm, plano-compressos, glabros; sementes 8-16, ca. $8 \times 4 \mathrm{~mm}$, reniformes, castanho-claras.

Material examinado: Mariana, Cibrão, 30.III.2005, fl., L.C.P. Lima et al. 321 (VIC); 16.VI.2005, fr., L.C.P. Lima et al. 364 (VIC).

As flores amarelas com pétalas orbiculares facilitaram o reconhecimento desta espécie no dossel da floresta estacional submontana do PEI. Floresceu de março a maio e frutificou de junho a setembro.

5. Senna macranthera (Collad.) H.S. Irwin \& Barneby var. nervosa (Vogel) H.S. Irwin \& Barneby, Mem. New York Bot. Gard. 35: 184. 1982.

Fig. $1 \mathrm{j}-\mathrm{m}$

Árvores 3-8 m alt., ramos estriados, tomentosos. Estípulas 3-5 mm compr., lineares, caducas; pecíolo 2,5-5,8 cm compr.; raque 1,8-3,8 cm compr., canaliculada; nectários entre todos os pares de folíolos, sésseis ou subsésseis, fusiformes. Folhas 4-folioladas, paripinadas; folíolos 8-13,8× 2,6-4,2 cm, opostos, oblongo-falcados, base oblíqua ou obtusa, ápice acuminado, face adaxial glabra, face abaxial tomentosa. Inflorescência paniculada, axilar ou terminal; pedúnculo 1,6-4 cm compr., tomentoso; raque 2,9-5,8 cm compr., tomentosa. Flores pentâmeras, zigomorfas, pediceladas; cálice 4-6 mm compr., dialissépalo, sépalas ovadas, pubescentes externamente; corola dialipétala, 2,9-3,7 cm compr., amarela, pétala centro adaxial orbicular; estames 7, heterodínamos, dialistêmones, em dois verticilos: 4 medianos e 3 abaxiais maiores, filetes retos ou curvados, 4-6 mm compr., tomentoso, anteras 5-8 mm compr., estaminódios 3; ovário ca. 1,6 cm compr., tomentoso na margem, estípite ca. 3 mm compr.; estilete ca. $1 \mathrm{~mm}$ compr., curvado, ciliado; estigma terminal, ciliado. Legumes bacóides, ca. $28 \times 1 \mathrm{~cm}$, cilíndricos, pubescentes; sementes ca. 160 , ca. $5 \times 3-4 \mathrm{~mm}$, ovadas, castanhas.

Material examinado: Mariana, estrada do Cibrão, 17.II.2005, fl., L.C.P. Lima et al. 305 (VIC); 27.IV.2005, fr., L.C.P. Lima et al. 350 (VIC); Ouro Preto, estrada em direção a Torre, 16.II.2005, fl., L.C.P. Lima \& S.C. Ferreira 292 (VIC).

Os folíolos oblongo-falcados e os nectários fusiformes diferenciam esta espécie das demais leguminosas da área de estudo. No PEI, foi coletada em florestas estacionais submontana e altimontana, floresceu de fevereiro a março e frutificou de abril a junho. 
6. Senna multijuga (Rich.) H.S. Irwin \& Barneby subsp. lindleyana (Gardner) H.S. Irwin \& Barneby, Mem. New York Bot. Gard. 35: 497. 1982. Fig. 1 n-p

Árvores 6-8 m alt., ramos estriados, ferrugíneotomentosos. Estípulas ca. 1,2 cm, linear-lanceoladas, caducas; pecíolo 1,5-2,5 cm compr.; raque (10)18$24 \mathrm{~cm}$ compr., canaliculada; nectários entre o primeiro par de folíolos, subsésseis, cilíndricos. Folhas (32)44-48-folioladas, paripinadas; folíolos 3,3-3,8× $0,7-0,9 \mathrm{~cm}$, opostos, oblongos, base oblíqua, ápice truncado ou mucronulado, ambas as faces pubescentes, tomentosos na nervura principal. Inflorescências racemosas; pedúnculo $1-1,5 \mathrm{~cm}$, ferrugíneo-pubescente; raque ca. $2 \mathrm{~cm}$ compr., ferrugíneo-pubescente. Flores pentâmeras, zigomorfas, pediceladas; cálice ca. $6 \mathrm{~mm}$ compr., sépala obovada, glabra externamente; corola dialipétala, ca. $2 \mathrm{~cm}$ compr., amarela, pétala centroadaxial obovada; estames 7 , heterodínamos, dialistêmones, em dois verticilos: 4 medianos e 3 abaxiais maiores, filetes retos ou curvados, 2-4 mm compr., glabros, anteras 6-7 mm compr., 3 estaminódios; ovário ca. $1,5 \mathrm{~cm}$ compr., tomentoso na margem, estípite ca. $3 \mathrm{~mm}$ compr.; estilete ca. 0,5 mm compr., curvado, glabro; estigma terminal, glabro. Legumes, ca. $9,5 \times 1,8 \mathrm{~cm}$, plano-compressos, puberulentos; sementes 16 , ca. $7 \times 2 \mathrm{~mm}$, oblongas, esverdeadas. Material selecionado: Ouro Preto, próximo a portaria do PEI, 21.I.2005, fl., L.C.P. Lima et al. 283 (VIC); trilha do Custódio, 20.X.2005, fr., L.C.P. Lima \& M.P. Andrade 394 (VIC).

Espécie semelhante a Cassia ferruginea var. ferruginea, quando estéril, devido aos folíolos oblongos e estípulas linear-lanceoladas, mas pode ser diferenciada pela presença de nectários entre o primeiro par de folíolos. O material analisado nas florestas estacionais altimontanas do PEI, apresentaram indumento mais denso do que o descrito por Irwin \& Barneby (1982). Entretanto, isto também foi observado por Bortoluzzi (2004) nos espécimes coletados em maiores altitudes em Santa Catarina. Floresceu em janeiro e frutificou em março e setembro.

7. Senna reniformis (G. Don) H.S. Irwin \& Barneby, Mem. New York Bot. Gard. 35: 223. 1982. Fig. 1 q-t

Arbustos ou arvoretas 1,5-5 m alt., ramos estriados, glabrescentes ou tomentosos. Estípulas 1,4-3,1 mm, reniformes, persistentes; pecíolo 1,52,5 cm compr.; raque $2,8-5$ cm compr., canaliculada; nectários entre todos os pares de folíolos, sésseis, piriformes. Folhas 6-folioladas, paripinadas; folíolos $6,7-9,5 \times 2,8-3,7 \mathrm{~cm}$, opostos, oblongos ou obovados, base obtusa, ápice agudo, face adaxial glabra, face abaxial glabrescente ou tomentosa, principalmente na nervura principal. Inflorescência racemosa, axilar ou terminal; pedúnculo 2-3,7 cm compr., tomentoso; raque $2-4 \mathrm{~cm}$ compr., tomentosa. Flores pentâmeras, zigomorfas, pediceladas; cálice ca. $1 \mathrm{~cm}$ compr., dialissépalo, sépalas oblongas, glabras externamente; corola dialipétala, ca. $2 \mathrm{~cm}$ compr., amarela, pétala centro-adaxial obovada; estames 7, heterodínamos, dialistêmones, em dois verticilos: 4 medianos e 3 abaxiais maiores, filetes retos ou curvados, 7-25 mm compr., glabros, anteras ca. $3 \mathrm{~mm}$ compr., estaminódios 3; ovário ca. 1,8 cm compr., pubescente, estípite ca. $4 \mathrm{~mm}$ compr.; estilete ca. $1 \mathrm{~mm}$ compr., curvado, glabro; estigma terminal, glabro. Legumes, 9-12×1-2 cm, plano-compressos, glabros; sementes 24-28, ca. $6 \times 5 \mathrm{~mm}$, oblongas, enegrecidas.

Material examinado: Mariana, trilha de Belém, 7.XII.2005, fl. e fr., L.C.P. Lima \& M.E.F. Araújo 235 (VIC); Ouro Preto, estrada da Torre, 6.XII.2004, fl. e fr., L.C.P. Lima \& O. Magalhães 232 (VIC); trilha Alcan, 25.IV.2005, fl., L.C.P. Lima \& E.D. Silva 333 (VIC).

Facilmente reconhecida pelas estípulas reniformes. Foi coletada em florestas estacionais submontana, montana e altimontana, floresceu de novembro a maio e frutificou de dezembro a agosto.

8. Tachigali friburgensis (Harms) L. Gomes da Silva \& H.C. Lima. Rodriguésia 58: 399. 2007. Sclerolobium friburgense Harms, Repert. Spec. nov. Regni veg. 24: 211. 1928.

Fig. 2 a-d

Árvores 8-20 m alt., ramos cilíndricos, pubescentes. Estípulas não observadas, caducas; pecíolo 2,4-3,6 cm compr.; raque 6-7,5 cm compr., triangular, não estriada; nectários ausentes. Folhas 10-16-folioladas, paripinadas; folíolos 8-13 ×5,5$6,5 \mathrm{~cm}$, opostos, elípticos ou lanceolados, base obtusa, ápice agudo, face adaxial glabrescente, face abaxial alvo-pubescente, nervuras terciárias inconspícuas. Inflorescências axilares. Flores não observadas. Criptossâmaras, 9,2-10 × 2,5-3 cm, plano-compressas, glabras; sementes 1 , ca. $1,2 \times 1 \mathrm{~cm}$, arredondada, enegrecida.

Material examinado: Mariana, estrada do Cibrão, 16.VI.2005, fr., L.C.P. Lima et al. 365 (VIC).

O número de folíolos e as nervuras terciárias inconspícuas são característicos desta espécie (Dwyer 1957). No PEI, ocorre em florestas estacionais altimontana e submontana, confirmando e ampliando a faixa altitudinal da espécie, que segundo Lima et al. (1994) seria acima de $1000 \mathrm{~m}$. Era citada apenas para os estados do Rio de Janeiro e São Paulo (Dwyer 1957; Lima et al. 1994), sendo este o primeiro 


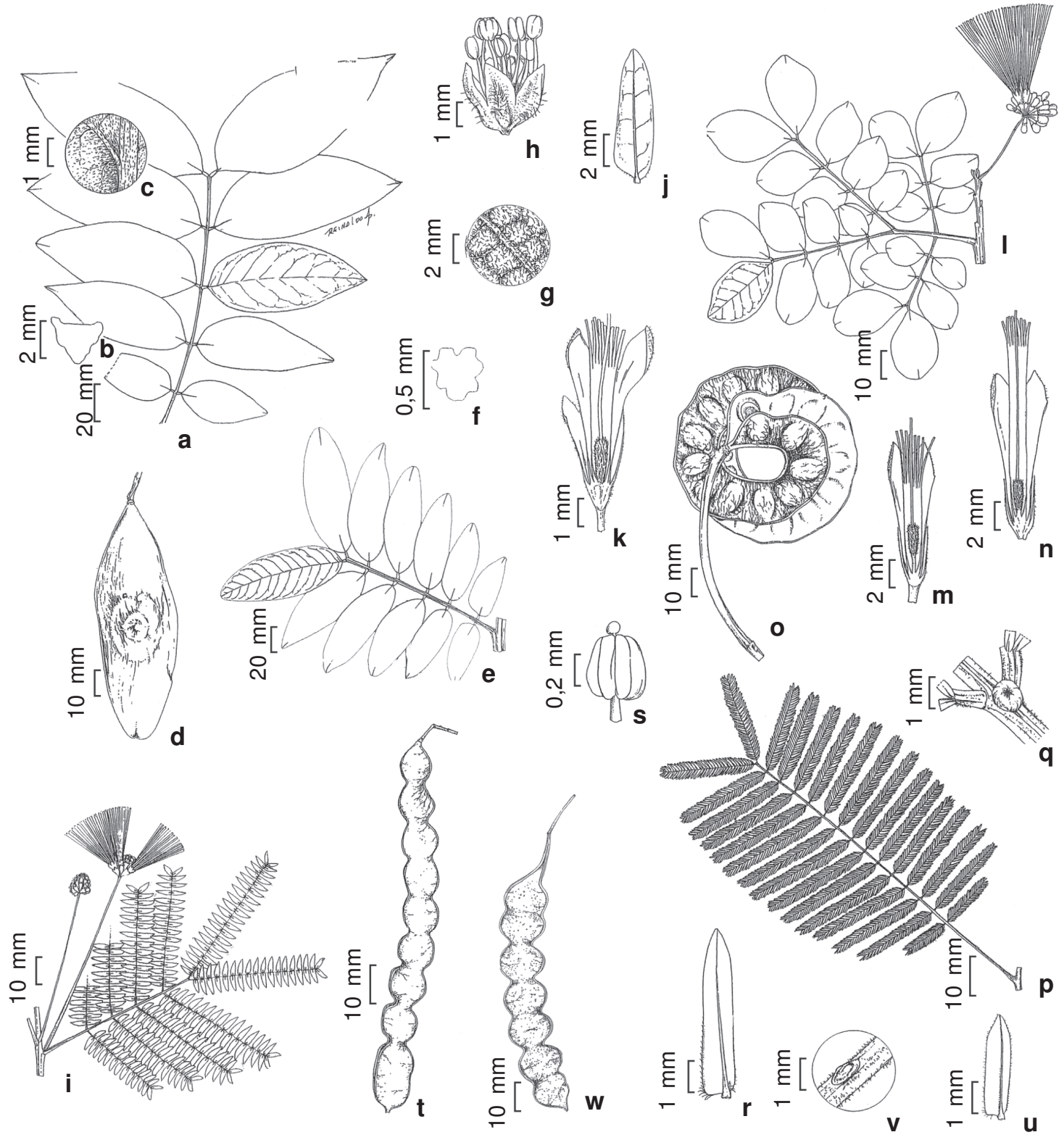

Figura 2 - a-d. Tachigali friburgensis (Lima 365) - a. folha; b. corte transversal da raque foliar; c. indumento e venação da face abaxial do folíolo; d. fruto. e-h. Tachigali rugosa (Lima 331) - e. folha; f. corte transversal da raque foliar; g. indumento e venação da face abaxial do folíolo; h. flor sem pétalas. i-k. Abarema langsdorffii (Lima 281) -i. ramo com inflorescência; j. foliólulo; k. flor em corte longitudinal. 1-o. Abarema obovata (1-n Lima 272; o Lima 234) -1. ramo com inflorescência; $\mathrm{m}$. flor periférica em corte longitudinal; $\mathrm{n}$. flor terminal em corte longitudinal; o. fruto. $\mathrm{p}$-t. Anadenanthera colubrina var. colubrina (Lima 303) - p. folha; q. detalhe do nectário entre o par de pina distal; r. foliólulo; s. antera; t. fruto. u-w. Anadenanthera peregrina (u-v Lima 395; w Lima 230) - u. foliólulo; v. detalhe do nectário peciolar; w. fruto.

Figure 2 - a-d. Tachigali friburgensis (Lima 365) - a. leaf; b. transverse section of the leaf raquis; c. indument and venation of the leaflet abaxial surface; d. fruit. e-h. Tachigali rugosa (Lima 331) - e. leaf; f. transverse section of the leaf raquis; g. indument and venation of leaflet abaxial surface; h. flower without petals. i-k. Abarema langsdorffii (Lima 281): i. flowering branch; j. leaflet; k. longitudinal section of the flower. 1-o. Abarema obovata (1-n Lima 272; o Lima 234) -1. flowering branch; m. longitudinal section of the peripheral flower; $n$. longitudinal section of the terminal flower; $\mathrm{o}$. fruit. p-t. Anadenanthera colubrina var. colubrina (Lima 303) - p. leaf; q. detail nectary between the pair of pinna distal; r. leaflet; s. anther; t. fruit. u-w. Anadenanthera peregrina (u-v Lima 395; w Lima 230) - u. leaflet; v. detail petiolar nectary; w. fruit. 
registro da espécie para Minas Gerais. Durante as expedições de campo, não foram observadas flores, apenas frutos, de junho a setembro.

9. Tachigali rugosa (Mart. ex Benth.) Zarucchi \& Pipoly, Sida 16: 407. 1995. Sclerolobium rugosum Mart ex Benth., Hooker's J. Bot. Kew Gard. Misc. 2: 237. 1850.

Fig. 2 e-h

Árvores 8-20 malt., ramos estriados, puberulentos. Estípulas ca. $6 \mathrm{~mm}$ compr., lanceoladas, caducas; pecíolos (1,4-)2-4,5 cm compr.; raque (3-)5,5-12 cm compr., cilíndrica, estriada; nectários ausentes. Folhas 10- ou 12-folioladas, paripinadas; folíolos 5,5-10,2× 2,1-3,6 cm, opostos, oblongos ou elípticos, base oblíqua ou obtusa, ápice agudo ou obtuso, face adaxial glabra, face abaxial áureo-tomentosa, nervuras terciárias conspícuas. Inflorescências em panícula de espigas, axilares; pedúnculo ca. 1,6 cm compr., tomentoso; raque ca. $2 \mathrm{~cm}$ compr., tomentosa. Flores pentâmeras, actinomorfas, sésseis; cálice ca. $4 \mathrm{~mm}$ compr., dialissépalo, sépalas ovadas, tomentosas externamente; corola ca. $3 \mathrm{~mm}$ compr., branca, pétalas linear-lanceoladas; estames 10, heterodínamos, dialistêmones, filetes ca. 5 mm compr., ferrugíneoseríceo na base, anteras ca. $1 \mathrm{~mm}$ compr., estaminódios ausentes; ovário ca. $2 \mathrm{~mm}$ compr., ferrugíneo-seríceo, estípite ca. $1 \mathrm{~mm}$ compr.; estilete ca. $1 \mathrm{~mm}$ compr., reto, ciliado; estigma terminal, glabro. Criptossâmaras, 8,5$10 \times 2,8-3,2 \mathrm{~cm}$, plano-compressas, glabras; sementes 1 , ca. $1,3 \times 1 \mathrm{~cm}$, ovadas, castanho-esverdeadas.

Material examinado: Ouro Preto, próximo a Fazenda do Manso, 8.X.1998, fl., A.V.M. Matos s.n. (OUPR 7538); 31.III.2005, fr., L.C.P. Lima et al. 331 (VIC).

As folhas de face abaxial áureo-tomentosa e as flores actinomorfas pequenas diferenciam esta espécie das Caesalpinioideae encontradas no PEI. Foi coletada em floresta estacional altimontana, florescendo de setembro a outubro e frutificando de março a maio.

\section{Mimosoideae}

10. Abarema langsdorffii (Benth.) Barneby \& J.W. Grimes, Mem. New York Bot. Gard. 74: 95. 1996.

Fig. $2 \mathrm{i}-\mathrm{k}$

Árvores (2-)6-15 m alt., ramos cilíndricos, tomentosos. Estípulas 1-2 mm compr., filiformes, caducas; pecíolo 1-2,5 cm compr., tomentoso; raque 3-11 cm compr., estriada, tomentosa; nectários sésseis, pateliformes, no pecíolo, entre as pinas dos pares distais e pares distais dos foliólulos. Folhas bipinadas, 4-10 pares de pinas; foliólulos 18-26 pares, 8-11 ×ca. $2 \mathrm{~mm}$, opostos, oblongo-subfalcados, base obtusa, ápice obtuso ou subagudo, ambas as faces glabras ou glabrescentes. Inflorescências racemosas, axilares, homomórficas; pedúnculo 4-6 cm compr., tomentoso; raque 8-12 mm compr. Flores pentâmeras, actinomorfas, sésseis ou curto-pediceladas; cálice 2,53 mm compr., campanulado, puberulento externamente; corola gamopétala, ca. $6 \mathrm{~mm}$ compr., pubescente externamente; estames 18-31, filetes alvos, tubo estaminal exserto, 5-8 mm compr., porção livre dos filetes 2,2-2,8 cm compr., glabros, anteras eglandulares; ovário ca. 1,5 mm compr., tomentoso, séssil; estilete 1,5-2,5 cm compr., glabro. Legumes, 0,8-1 cm larg., circinados, plano-compressos, puberulentos, margem sinuosa, torcida, ápice agudo; sementes 10-12, 5-6 × ca. $5 \mathrm{~mm}$, arredondadas, bicolores azuis e brancas.

Material selecionado: Mariana, estrada para trilha de Belém, 21.I.2005, fl., L.C.P. Lima et al. 281 (VIC); Ouro Preto, trilha do Baú, 5.III.1994, fl., M.B. Roschel \& S.J.L. Dias s.n. (OUPR 1328); 20.V.2005, fl. e fr., L.C.P. Lima et al. 357 (VIC).

Os foliólulos oblongo-subfalcados, inflorescências racemosas, homomórficas são características que distinguem Abarema langsdorffii de A. obovata. No PEI, ocorre em florestas estacionais montana, submontana e altimontana, floresceu e frutificou de janeiro a maio.

11. Abarema obovata (Benth.) Barneby \& J.W. Grimes, Mem. New York Bot. Gard. 74: 91. 1996.

Fig. $21-0$

Árvores 2-7 m alt., ramos cilíndricos, tomentosos. Estípulas não observadas, caducas; pecíolo 1-2,4 cm compr., tomentoso; raque 2-5,5 cm compr., canaliculada, tomentosa; nectários sésseis, pateliformes, entre todos os pares de pinas e pares de folíólulos. Folhas bipinadas, 2 ou 3 pares de pinas; foliólulos 3 ou 4 pares, 2-6 $\times 1-2,8 \mathrm{~cm}$, opostos ou subopostos, ovado-rômbicos, base oblíqua, ápice obtuso, ambas as faces glabras. Inflorescências umbeliformes em fascículos axilares ou terminais, heteromórficas; pedúnculo $2,7-3,5 \mathrm{~cm}$ compr., tomentoso; raque globosa, diâmetro da inflorescência 5-6 mm (excluindo os filetes). Flores pentâmeras, actinomorfas, sésseis ou pediceladas; flores periféricas pediceladas, pedicelo ca. $2 \mathrm{~mm}$ compr.; cálice ca. 3 mm compr., campanulado, ferrugíneo-tomentoso externamente; corola gamopétala, ca. $8 \mathrm{~mm}$ compr., ferrugínea-pubescente externamente; estames 28, filetes alvos, tubo estaminal incluso, 3-4 mm compr., porção livre dos filetes 3,2-3,8 cm compr., glabros, anteras eglandulares; ovário ca. 1,5 mm compr., pubescente, estípite ca. $2 \mathrm{~mm}$ compr.; estilete ca. 3,6 cm compr., 
glabro; flores terminais sésseis; cálice ca. $4 \mathrm{~mm}$ compr., tubuloso, glabrescente; corola ca. 1,3 cm compr., glabrescente externamente; estames ca. 34, tubo estaminal exserto, ca. 1,8 cm compr., porção livre dos filetes $2 \mathrm{~cm}$ compr., glabros; ovário ca. 2,5 mm compr., pubescente, séssil; estilete ca. 2,4 cm compr. Legumes, 1,2-2 cm larg., circinados, plano-compressos, glabros, margem sinuosa torcida, ápice agudo; sementes 10-16, 7-8 ×7 mm, arredondadas, bicolores azuis e brancas.

Material selecionado: Mariana, trilha de Belém, 7.XII.2004, fr., L.C.P. Lima \& M.E.F. Araújo 234 (VIC); 20.I.2005, fl., L.C.P. Lima et al. 272 (VIC).

As folhas bipinadas de foliólulos ovadorômbicos e inflorescências heteromorfas distinguem Abarema obovata das demais Leguminosae do PEI. Espécimes coletados no PEI e depositados nos herbários VIC (Dias \& Roschel s.n. VIC 28471) e OUPR (Messias \& Roschel s.n. OUPR 1218) estavam erroneamente identificados como Piptadenia rigida e Pithecelobium sp., respectivamente. Entretanto, estes exemplares apresentaram androceu com mais de 10 estames monadelfos, legume circinado e sementes bicolores com pleurograma, características diagnósticas de Abarema, segundo Barneby \& Grimes (1996). No PEI, ocorre nas florestas estacionais montana, submontana e altimontana, floresceu de dezembro a janeiro e frutificou de setembro a fevereiro.

12. Anadenanthera colubrina var. colubrina (Vell.) Brenan, Kew Bull. 10: 182. 1955. Fig. 2 p-t Árvores 8-12 m alt., ramos cilíndricos, glabros ou pubescentes. Estípulas 5-6 mm compr., linearlanceoladas, caducas; pecíolo 3,5-5,5 cm compr., puberulento; raque $12-16 \mathrm{~cm}$ compr., canaliculada, puberulenta, nectários sésseis, globosos, no pecíolo e entre os pares de pinas distais. Folhas bipinadas, 13-18 pares de pinas; foliólulos 48-60 pares, 4-5 × ca. $1 \mathrm{~mm}$, opostos, oblongos, base oblíqua, ápice agudo, ambas as faces glabras, ciliado. Inflorescências capituliformes reunidas em panículas terminais ou fascículos axilares, homomórficas; pedúnculo 7-8 mm compr., pubescente; raque globosa, diâmetro da inflorescência 6-8 mm (excluindo os filetes). Flores pentâmeras, actinomorfas, sésseis; cálice 1-1,2 mm compr., campanulado, pubescente externamente; corola gamopétala, 2,2-3 mm compr., pubescente externamente; estames 10, filetes alvos, livres, 6-8 mm compr., glabros, anteras glandulares na antese; ovário 0,8-1 mm compr., glabro, estípite $0,1-0,2$ mm compr.; estilete 6-6,5 mm compr., glabro. Folículos, 19-24 × 1,8-1,9 cm, retos, plano-compressos, glabros, margem regularmente constricta entre as sementes, ápice apiculado; sementes 10-12, ca. 1,1 $\times 1 \mathrm{~cm}$, arredondadas, unicolores, enegrecidas.

Material examinado: Mariana, Cibrão, 17.II.2005, fl., L.C.P. Lima et al. 303 (VIC); 30.III.2005, fr., L.C.P. Lima et al. 322 (VIC).

Dentre as Mimosoideae do PEI, Anadenanthera colubrina é semelhante vegetativamente a Pseudopiptadenia contorta, porém a forma do nectário permite diferenciá-las. No PEI, foi coletada em floresta estacional submontana, floresceu e frutificou de dezembro a março.

13. Anadenanthera peregrina (L.) Speg., Physis (Buenos Aires) 6: 314. 1923.

Fig. $2 \mathrm{u}-\mathrm{w}$

Árvores 10-12 m alt., ramos cilíndricos, tomentosos. Estípulas 1-2 mm compr., ovadas, caducas; pecíolo 2-2,5 cm compr., tomentoso; raque $6-8,5 \mathrm{~cm}$ compr., canaliculada, tomentosa; nectários sésseis, pateliformes, oblongos, entre os pares de pinas distais. Folhas bipinadas, 14 ou 15 pares de pinas; foliólulos ca. 54 pares, $2-3 \times$ ca. 0,5 mm, opostos, oblongos, base oblíqua, ápice agudo, face adaxial tomentosa, face abaxial puberulenta, ciliado. Inflorescências capituliformes reunidas em fascículos axilares, homomórficas; pedúnculo ca. 1,7 cm compr., alvo-tomentoso; raque globosa, diâmetro da inflorescência ca. $1 \mathrm{~cm}$ (excluindo os filetes). Flores pentâmeras, actinomorfas, sésseis; cálice ca. $2 \mathrm{~mm}$ compr., campanulado, pubescente externamente; corola gamopétala, ca. 4 mm compr., glabra externamente; estames 10, filetes alvos, livres, ca. $5 \mathrm{~mm}$ compr., glabros, anteras eglandulares; ovário 1-1,2 mm compr., glabro, estípite ca. 0,2 mm compr.; estilete ca. $5 \mathrm{~mm}$ compr., glabro. Folículos, ca. $19 \times 3 \mathrm{~cm}$, retos, plano-compressos, verrucosos, margem irregularmente constricta entre as sementes, ápice apiculado; sementes ca. 7, ca. $3 \times 1,5 \mathrm{~mm}$, oblongas, castanho-escuras.

Material examinado: Ouro Preto, trilha do Custódio, 20.X.2005, fl., L.C.P. Lima \& M.P. Andrade 395 (VIC). Material adicional: Viçosa, Universidade Federal de Viçosa, Vila Gianetti, 10.XI.2004, fl. e fr., L.C.P. Lima \& C. A. Costa 230 (VIC).

Anadenanthera peregrina difere de $A$. colubrina pelo nectário oblongo, anteras eglandulares e fruto de superfície verrucosa. No PEI, foi coletada em floresta estacional altimontana, floresceu em outubro, mas não frutificou no período de estudo. 
14. Calliandra parvifolia (Hook. \& Arn.) Speg., Revista Argent. Agron. 1: 193. $1926 . \quad$ Fig. 3 a-e Arbustos ou arvoretas 1,5-5 m alt., ramos cilíndricos, glabros ou glabrescentes. Estípulas 3$7 \mathrm{~mm}$ compr., lanceoladas, persistentes; pecíolo 0,8$1,2 \mathrm{~cm}$ compr., tomentoso; raque 5-8,2 cm compr., canaliculada, tomentosa; nectários ausentes. Folhas bipinadas, 8-20 pares de pinas; foliólulos 30-48 pares, 2-3,5 × 0,5-0,8 cm, opostos, oblongos, base oblíqua, ápice obtuso, margem ciliada, face abaxial glabra, face adaxial tomentosa na base, ambas as faces com pontuações. Inflorescências umbeliformes, axilares, heteromórficas; pedúnculo 1,3-1,6 cm compr., viloso; raque globosa, diâmetro da inflorescência 9-10 mm (excluindo filetes). Flores pentâmeras ou hexâmeras, actinomorfas, sésseis ou pediceladas; flores periféricas pentâmeras, pediceladas, pedicelo $0,5-0,8 \mathrm{~mm}$ compr.; cálice $2-$ 2,2 mm compr., funiliforme, tomentoso externamente; corola gamopétala, 4-5 mm compr., tomentosa externamente; estames 16 , filetes alvos na base e avermelhados no ápice, tubo estaminal incluso, ca. $3 \mathrm{~mm}$ compr., porção livre dos filetes $3,2-3,5 \mathrm{~cm}$ compr., glabros, anteras eglandulares; ovário ca. 1,2 mm compr., glabro, estípite ca. 0,1 mm compr.; estilete ca. 2,2 cm compr., glabro; flores terminais hexâmeras, sésseis; cálice ca. $3 \mathrm{~mm}$ compr., campanulado, indumento tomentoso externamente; estames 22; estilete ca. 3,8 cm compr. Legumes, 7$11 \times 0,9-1,3 \mathrm{~cm}$, levemente recurvados, planocompressos, glabros ou puberulentos, margem reta espessa, ápice caudado; sementes 5-10, 4-5 × 2-3 $\mathrm{mm}$, obovadas, castanhas.

Material examinado: Mariana, estrada do Cibrão, 7.XII.2004, fr., L.C.P. Lima \& M.E.F. Araújo 248 (VIC); 26.IX.2005, fl., L.C.P. Lima \& F.C.P. Garcia 382 (VIC).

Os estames com filetes alvos na base e avermelhados no ápice facilitam o reconhecimento desta espécie no PEI. Foi coletada em floresta estacional submontana, floresceu em maio e de setembro a novembro, frutificando o ano todo.

\section{Inga cylindrica (Vell.) Mart., Flora 20(2, Beibl.): 114. 1837. \\ Fig. $3 \mathrm{f}-\mathrm{i}$}

Arvoretas ou árvores 1,5-12 m alt., ramos cilíndricos, glabros ou tomentosos. Estípulas 2-3 mm compr., oblanceoladas, caducas; pecíolo 1,4-2 cm compr., pubérulo; raque 4,5-8,2 cm compr., marginada, pubérula, nectários sésseis, circulares, entre todos os pares de folíolos. Folhas 6-10folioladas; folíolos 6,2-12,3 × 1-3,4 cm, opostos, elípticos, base aguda, ápice agudo, ambas as faces glabras ou puberulentas. Inflorescências espiciformes, axilares, homomórficas; pedúnculo 2,4-5,2 cm compr., pubescente ou tomentoso; raque 3,5-5 cm compr. Flores pentâmeras, actinomorfas, sésseis; cálice ca. $1 \mathrm{~mm}$ compr., campanulado, pubérulo externamente; corola gamopétala, ca. 4,5 mm compr., pubérula externamente; estames 3235 , filetes alvos, tubo estaminal incluso, ca. $4 \mathrm{~mm}$ compr., porção livre dos filetes 4-5 mm compr., glabros, anteras eglandulares; ovário ca. 1,5 mm compr., glabrescente, séssil; estilete 2,5-3 mm compr., glabro. Legumes nucóides, 12-16×1,7-2 $\mathrm{cm}$, retos, plano-compressos, glabros ou glabrescentes, margem constricta, ápice mucronulado; sementes 8-12, ca. $10 \times 6 \mathrm{~mm}$, elípticas, castanho-claras, com sarcotesta.

Material selecionado: Mariana, estrada do Cibrão, 7.XII.2004, fr., L.C.P. Lima \& M.E.F. Araújo 244 (VIC); 26.IX.2005, fl., L.C.P. Lima \& F.C.P. Garcia 383 (VIC).

A raque foliar marginada e as folhas 6-10folioladas diferem Inga cylindrica das demais espécies de Inga do Parque. No PEI, está distribuída nas florestas estacionais submontana, montana e altimontana, floresceu de setembro a novembro e frutificou em dezembro.

16. Inga edulis Mart., Flora 20(2, Beibl.): 113. 1837. Fig. $3 \mathrm{j}-\mathrm{m}$

Árvores 12-15 m alt., ramos estriados, ferrugíneo-tomentosos. Estípulas 6-7 mm compr., lineares, caducas; pecíolo 3-3,5 cm compr., tomentoso; raque 14,5-19 cm compr., alada, tomentosa; nectários sésseis, transversalmentecomprimidos, entre todos os pares de folíolos. Folhas 10- ou 12-folioladas; folíolos 14-18,5×6$9,5 \mathrm{~cm}$, opostos, elíptico-ovados, base obtusa ou aguda, ápice agudo, ambas as faces tomentosas. Inflorescências espiciformes axilares ou terminais, homomórficas; pedúnculo 1,7-2 cm compr., tomentoso; raque 1,4-2 cm compr. Flores pentâmeras, actinomorfas, sésseis; cálice ca. $7 \mathrm{~mm}$ compr., tubuloso, tomentoso externamente; corola gamopétala, ca. 1,6 cm compr., serícea externamente; estames ca. 60, filetes cremes, tubo estaminal incluso, ca. 1,6 cm compr., porção livre dos filetes ca. 3,2 cm compr., glabros, anteras eglandulares; ovário ca. $2 \mathrm{~mm}$ compr., glabro, séssil; estilete ca. 2,8 cm compr., glabro. Legumes nucóides, ca. $23 \times$ $0,6 \mathrm{~cm}$, retos, cilíndricos, tomentosos, margem sulcada longitudinalmente, ápice agudo; sementes não observadas.

Material examinado: Mariana, Cibrão, 19.X.2005, L.C.P. Lima et al. 410 (VIC). 

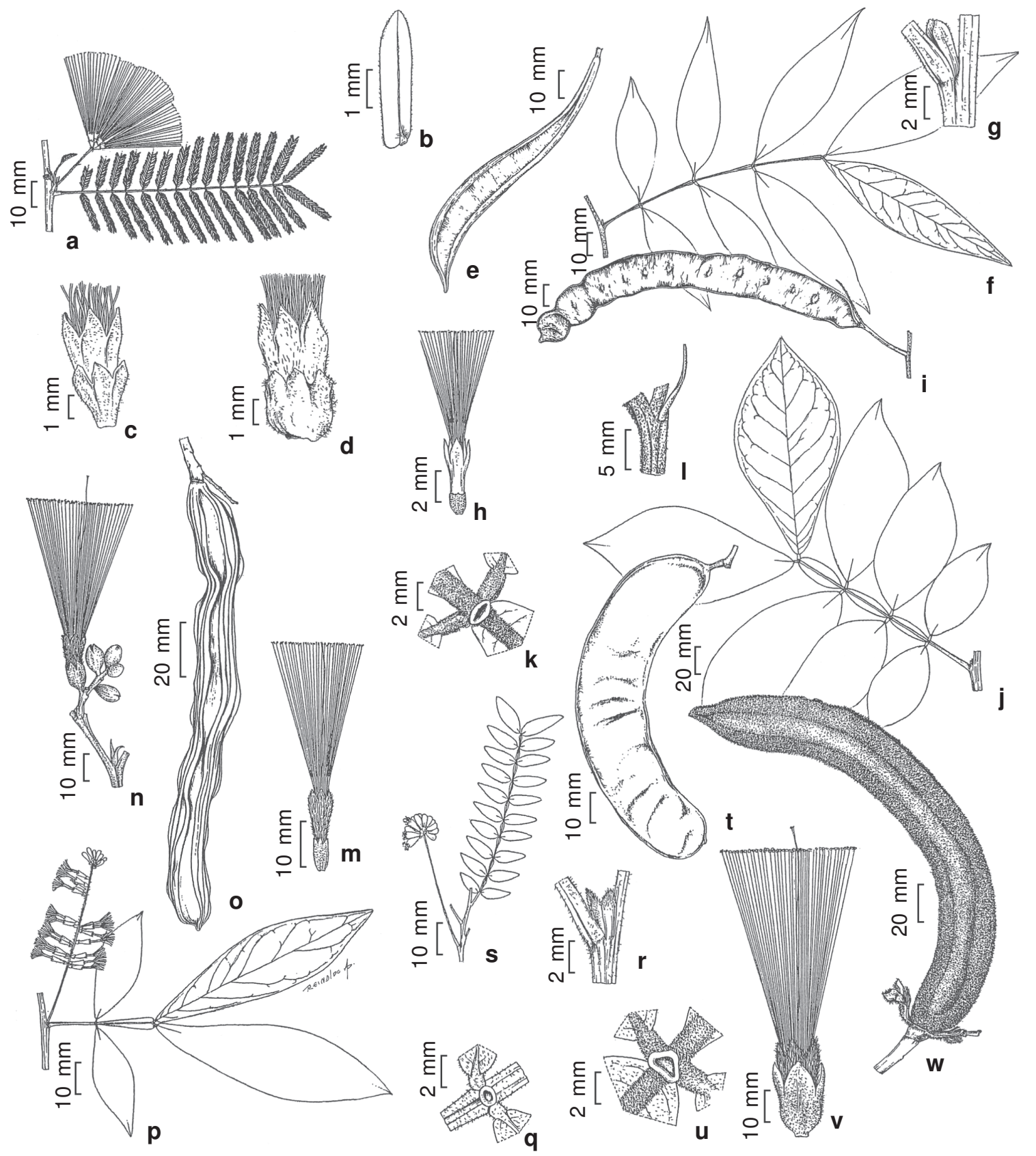

Figura 3 - a-e. Calliandra parvifolia (a-d Lima 382; e Lima 248) - a. ramo com inflorescência; b. face adaxial do folíolo; c. flor periférica; d. flor terminal; e. fruto. f-i. Inga cylindrica (f-h Lima 383; i Lima 244) - f. folha; g. estípula; h. flor; i. fruto. j-m. Inga edulis (j-k Nunes 118; 1 Lima 410; m Tameirão-Neto 2661) - j. folha; k. nectário; 1. estípula; $\mathrm{m}$. flor. n-o. Inga ingoides (n Valente 379; o Lima 296): n. inflorescência; o. fruto. p-r. Inga marginata (Lima 267) - p. ramo com inflorescência; q. nectário; r. estípula. s-t. Inga schinifolia (s Magalhães-Gomes s.n. OUPR 4568; t Messias 272) - s. ramo com inflorescência; t. fruto. u-w. Inga sessilis (Lima 226) - u. nectário; v. flor; w. fruto.

Figure 3 - a-e. Calliandra parvifolia (a-d Lima 382; e Lima 248) - a. flowering branch; b. adaxial surface of leaflet; c. peripheral flower; d. terminal flower; e. fruit. f-i. Inga cylindrica (f-h Lima 383; i Lima 244) - f. leaf; g. stipule; h. flower; i. fruit. j-m. Inga edulis (j-k Nunes 118; 1 Lima 410; m Tameirão-Neto 2661) - j. leaf; k. nectary; 1. stipule; m. flower. n-o. Inga ingoides (n Valente 379; o Lima $296)$ - n. inflorescence; o. fruit. p-r. Inga marginata (Lima 267) - p. flowering branch; q. nectary; r. stipule. s-t. Inga schinifolia (s Magalhães-Gomes s.n. OUPR 4568; t Messias 272): s. flowering branch; t. fruit. u-w. Inga sessilis (Lima 226) - u. nectary; v. flower; w. fruit. 
Material adicional: Mariana, UHE Fumaça, 18.XII.1997, fl., E. Tameirão-Neto 2661 (VIC); Marliéria, Parque Estadual do Rio Doce, trilha do Aníbal, 27.XI.2001, fr., S.R.D.F.S. Nunes et al. 118 (VIC).

É semelhante a Inga vera subsp. affinis e I. ingoides, das quais se diferencia principalmente pelo nectários foliares transversalmente comprimidos. No PEI, foi coletada em floresta estacional submontana, mas não floresceu nem frutificou no período de estudo.

17. Inga ingoides (Rich.) Willd., Sp. pl. (ed. 4) 4(2): 1012. 1806.

Fig. 3 n-o

Árvores 6-15 m alt., ramos cilíndricos, tomentosos. Estípulas ca. $3 \mathrm{~mm}$ compr., ovadas, caducas; pecíolo 1-3 cm compr., tomentoso; raque 7,5-14 cm compr., alada, tomentosa; nectários sésseis, circulares ou triangulares, entre todos os pares de folíolos. Folhas 10-folioladas; folíolos 7,5$16,5 \times 1,7-6 \mathrm{~cm}$, opostos, elípticos ou obovados, base aguda ou obtusa, ápice cuspidado, face adaxial pubescente, face abaxial tomentosa. Inflorescências racemosas, axilares, homomórficas; pedúnculo 4$2,1 \mathrm{~cm}$ compr., tomentoso; raque 1,5-2,5 cm compr. Flores pentâmeras, actinomorfas, pedicelo 2-3 mm compr.; cálice 1,3-1,4 cm compr., campanulado, tomentoso externamente; corola gamopétala, ca. 2 cm compr., lanosa externamente; estames ca. 42, filetes alvos, tubo estaminal incluso, ca. $6 \mathrm{~mm}$ compr., porção livre dos filetes ca. $4 \mathrm{~cm}$ compr., glabros, anteras eglandulares; ovário ca. $6 \mathrm{~mm}$ compr., glabro, séssil; estilete ca. 4,6 cm compr., glabro. Legumes nucóides, 12,5-22,5 × 0,8-1,5 cm, retos, cilíndricos, tomentosos, margem longitudinalmente estriada, ápice mucronulado; sementes ca. 18 , ca. $8 \times$ $6 \mathrm{~mm}$, ovadas, castanho-escuras, com sarcotesta.

Material examinado: Mariana, Cibrão, 17.II.2005, fr., L.C.P. Lima et al. 296 (VIC); trilha de Belém, 8.XII.2004, fr., L.C.P. Lima \& M.E.F. Araújo 256 (VIC).

Material adicional: Paraopeba, Flona, 18.III.1999, fl., G. Valente \& J.A.A. Meira-Neto 379 (VIC).

Inga ingoides pode ser confundida com I. vera subsp. affinis, da qual difere pelos frutos maiores e o número de sementes. No PEI, foi coletada em florestas estacionais submontana e montana; frutificou, porém não floresceu no período de estudo.

18. Inga marginata Willd., Sp. pl. (ed. 4) 4(2): 1015. 1806.

Fig. 3 p-r

Árvores ca. $5 \mathrm{~m}$ alt., ramos cilíndricos, puberulentos. Estípulas ca. $2 \mathrm{~mm}$ compr., ovadas, caducas; pecíolo 1,8-3,5 cm compr., tomentoso; raque 1,6-4 cm compr., alada, tomentosa; nectários subsésseis, circulares, entre todos os pares de folíolos. Folhas 4-folioladas; folíolos 8,5-10 × 2,5$2,9 \mathrm{~cm}$, opostos, elípticos, base aguda, ápice agudo, ambas as faces glabras ou puberulentas. Inflorescências espiciformes, axilares, homomórficas; pedúnculo 0,8-1,3 mm compr., tomentoso; raque 4,3$7 \mathrm{~cm}$ compr. Flores pentâmeras, actinomorfas, sésseis; cálice 1,1-1,5 cm compr., campanulado, pubérulo externamente; corola gamopétala, ca. $5 \mathrm{~mm}$ compr., glabra ou pubérula externamente; estames 35 ou 36, filetes alvos, tubo estaminal exserto, ca. $7 \mathrm{~mm}$ compr., porção livre dos filetes 5-6 mm compr., glabros, anteras eglandulares; ovário ca. 1,1 mm compr., glabrescente, séssil; estilete ca. 1,1 cm compr., glabro. Legumes nucóides imaturos, ca. 11,2×0,9 cm, retos, planocompressos, glabros, margem constricta, ápice apiculado; sementes 10, imaturas, com sarcotesta. Material examinado: Mariana, Cibrão, 20.I.2005, fl. e fr., L.C.P. Lima et al. 267 (VIC).

As folhas 4-folioladas, estípulas ovadas e o fruto glabro diferem esta das demais espécies de Inga das florestas do PEI. Foi coletada em floresta estacional submontana, floresceu e frutificou em janeiro.

19. Inga schinifolia Benth., London J. Bot. 4: 584. 1845.

Fig. $3 \mathrm{~s}-\mathrm{t}$

Arbustos ou arvoretas ca. $3 \mathrm{~m}$ alt., ramos cilíndricos, gabros. Estípulas 3-4 mm compr., linearlanceoladas, caducas; pecíolo 0,3-1,3 cm compr., glabro ou glabrescente; raque 2,9-11,5 cm compr., marginada, glabra ou glabrescente; nectários estipitados, circulares, entre todos os pares de folíolos. Folhas (14)16-28-folioladas; folíolos 1,32,5 × 0,4-0,9 cm, opostos, rômbicos ou elípticos, base aguda, ápice agudo ou mucronulado, ambas as faces glabras. Inflorescências umbeliformes, axilares, homomórficas; pedúnculo 3,4 cm compr., pubérulo; raque globosa, diâmetro da inflorescência 1,2-1,3 cm (excluindo os filetes). Flores pentâmeras, actinomorfas, curto-pediceladas, pedicelo ca. $0,1 \mathrm{~mm}$ compr.; cálice 1-1,2 mm compr., campanulado, pubérulo externamente; corola gamopétala, 5-5,2 mm compr., pubérula externamente; estames 22-24, filetes alvos, tubo estaminal exserto, ca. $6 \mathrm{~mm}$ compr., porção livre dos filetes ca. $6 \mathrm{~mm}$ compr., glabros, anteras eglandulares; ovário ca. 1 mm compr., glabro, estípite ca. 0,1 mm compr.; estilete ca. 1,2 cm compr., glabro. Legumes nucóides, ca. $9 \times 9,5 \mathrm{~cm}$, levemente recurvados, plano-compressos, glabros, margem inteira, ápice apiculado; sementes 16 , ca. $11 \times 5 \mathrm{~mm}$, oblongas, enegrecidas, com sarcotesta. 
Material examinado: Ouro Preto, trilha do Baú, 15.VI.2005, L.C.P. Lima \& F.C.P. Garcia 391 (VIC). Material adicional: Ouro Preto, APA das Andorinhas, Serra da Brígida, 18.X.1999, fr., M.C.T.B. Messias 272 (OUPR); Morro São Sebastião, 27.II.1895, fl., C.F. Magalhães-Gomes s.n. (OUPR 4568).

O número e tamanho dos folíolos são características que facilitam o reconhecimento desta espécie nas florestas do PEI. Foi coletada em floresta estacional altimontana, porém não floresceu nem frutificou no período de estudo.

20. Inga sessilis (Vell.) Mart., Flora 20(2, Beibl.): 114. 1837.

Fig. $3 \mathrm{u}-\mathrm{w}$

Árvores 3-12 m alt., ramos cilíndricos, ferrugíneo-velutinos. Estípulas ca. 1,5 cm compr., ovado-lanceoladas, caducas; pecíolo 3,5-6,2 cm compr., ferrugíneo-velutino; raque 14-20 cm compr., alada, ferrugíneo-velutina; nectários sésseis, circulares ou triangulares, entre todos os pares de folíolos. Folhas 12-folioladas; folíolos 12,5-20,5× 6-8 cm, opostos, elípticos, base aguda, ápice agudo, face adaxial pubescente, face abaxial ferrugíneo-tomentosa. Inflorescências espiciformes, axilares, homomórficas; pedúnculo ca. $5 \mathrm{~cm}$ compr., tomentoso; raque ca. $3,5 \mathrm{~cm}$ compr. Flores pentâmeras, actinomorfas, sésseis; cálice ca. $2,5 \mathrm{~mm}$ compr., campanulado, tomentoso externamente; corola gamopétala, ca. 2,8 cm compr., velutina externamente; estames ca. 216, filetes alvos, tubo estaminal incluso, ca. 1,6 cm compr., porção livre dos filetes ca. $7 \mathrm{~cm}$ compr., glabros, anteras eglandulares; ovário ca. 4 mm compr., glabro, séssil; estilete ca. $8,4 \mathrm{~cm}$ compr., glabro. Legumes nucóides, 10,5-20,5 × 1,8-2,5 cm, recurvados, plano-compressos, velutinos, margem estriada, ápice apiculado; semente não observada.

Material examinado: Ouro Preto, estrada da Torre, 26.IX.2005, fr., L.C.P. Lima et al. 358 (VIC); estrada para Fazenda do Manso, 23.VII.1994; fl., M.B. Roschel s.n. (OUPR 1439); trilha da Alcan, 24.X.2004, fr., L.C.P. Lima \& F.C.P. Garcia 226 (VIC).

$\mathrm{O}$ indumento velutino nos ramos e frutos caracteriza esta espécie de Inga. No PEI, foi coletada em floresta estacional altimontana, floresceu em junho e agosto e frutificou em março e outubro.

\section{Inga vera subsp. affinis (DC.) T.D. Penn., Gen.} Inga, Bot.: 716. 1997.

Fig. $4 \mathrm{a}-\mathrm{b}$

Árvores 5-6 m alt., ramos cilíndricos, ferrugíneo-tomentosos. Estípulas 3-4 mm compr., ovadas, caducas; pecíolo 1,5-3 cm compr., ferrugíneo-tomentoso; raque 7-12,5 cm compr., alada, ferrugíneo-tomentosa; nectários sésseis, circulares, entre todos os pares de folíolos. Folhas 8- ou 10-folioladas; folíolos 9-14,5 × 5-5,4 cm, opostos, elípticos ou obovados, base aguda, ápice acuminado ou apiculado, face adaxial pubescente ou tomentosa, face abaxial tomentosa. Inflorescências espiciformes ou racemosas, axilares, homomórficas; pedúnculo 3-3,5 cm compr., tomentoso; raque 3,3-4 cm compr. Flores pentâmeras, actinomorfas, sésseis ou curtopediceladas, pedicelo ca. $1 \mathrm{~mm}$ compr.; cálice 5-7 mm compr., campanulado, tomentoso externamente; corola gamopétala, 1,8-2,1 cm compr., serícea externamente; estames 118-120, filetes alvos, tubo estaminal incluso, ca. $1,5 \mathrm{~cm}$ compr., porção livre dos filetes ca. $3,8 \mathrm{~cm}$ compr., glabros, anteras eglandulares; ovário ca. 3 mm compr., glabro, séssil; estilete ca. 5,1 cm compr., glabro. Legumes nucóides, 9,5-10 × 1,8-2,5 cm, retos, cilíndricos, ferrugíneotomentosos, margem estriada longitudinalmente, ápice cuspidado; sementes 10 , ca. $10 \times 8 \mathrm{~mm}$, arredondadas, castanho-escuras, com sarcotesta. Material examinado: Mariana, trilha de Belém, 26.IV.2005, fr., L.C.P. Lima et al. 341 (VIC); Ouro Preto, 1.X.1998, fl., H.C. Sousa et al. 214 (OUPR; VIC).

O número de estames e o comprimento do fruto auxiliam a diferenciar esta das demais espécies de Inga das florestas do PEI. Foi coletada em florestas estacionais montana e altimontana, e observada em floresta estacional submontana; não foram observadas flores no período de estudo, mas frutos de fevereiro a março.

22. Inga vulpina Mart. ex Benth., Trans. Linn. Soc. London 30: 625.1875.

Fig. 4 c-e

Arbustos ou árvores 2-8 m alt., ramos cilíndricos, ferrugíneo-hirsutos. Estípulas 3-4 mm compr., ovadas, caducas; pecíolo 1-2,5 cm compr., ferrugíneo-hirsuto; raque 3,5-6,8 cm compr., alada, ferrugíneo-hirsuta; nectários estipitados, cupuliformes, entre todos os pares de folíolos. Folhas 6- ou 8-folioladas; folíolos 6,5-9,2 2 2-3,5 $\mathrm{cm}$, opostos, elípticos ou lanceolados, base aguda, ápice agudo ou apiculado, face adaxial glabrescente, face abaxial hirsuta. Inflorescências espiciformes, axilares, homomórficas; pedúnculo 5-6 cm compr., tomentoso; raque ca. $2 \mathrm{~cm}$ compr. Flores pentâmeras, actinomorfas, sésseis; cálice 6,5-7 mm compr., campanulado, hirsuto externamente; corola gamopétala, 12,2-13 $\mathrm{mm}$ compr., setosa externamente; estames 52-58, filetes róseos, tubo estaminal incluso, ca. $8 \mathrm{~mm}$ compr., porção livre dos filetes 2-2,2 cm compr., glabros, anteras 

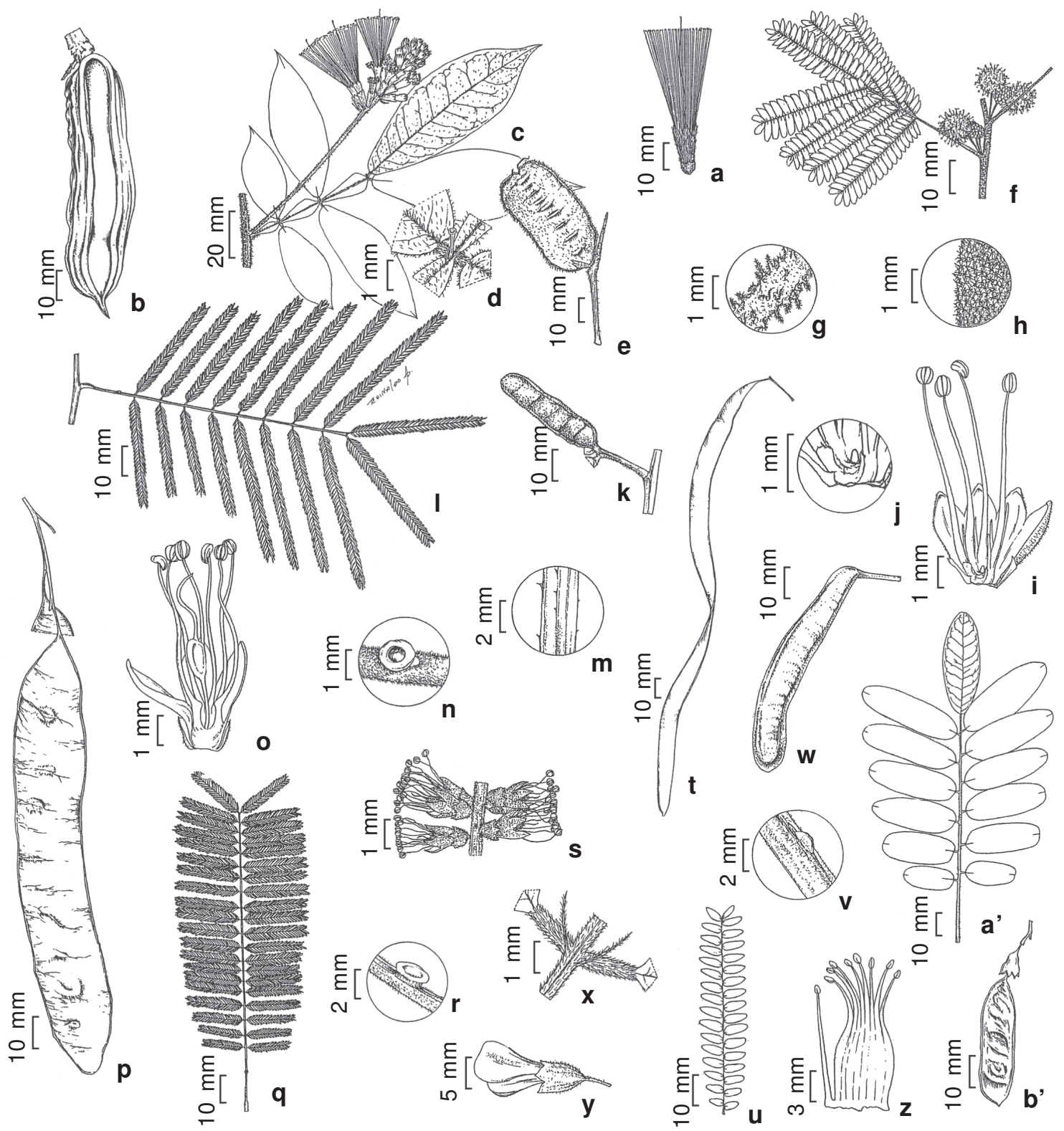

m
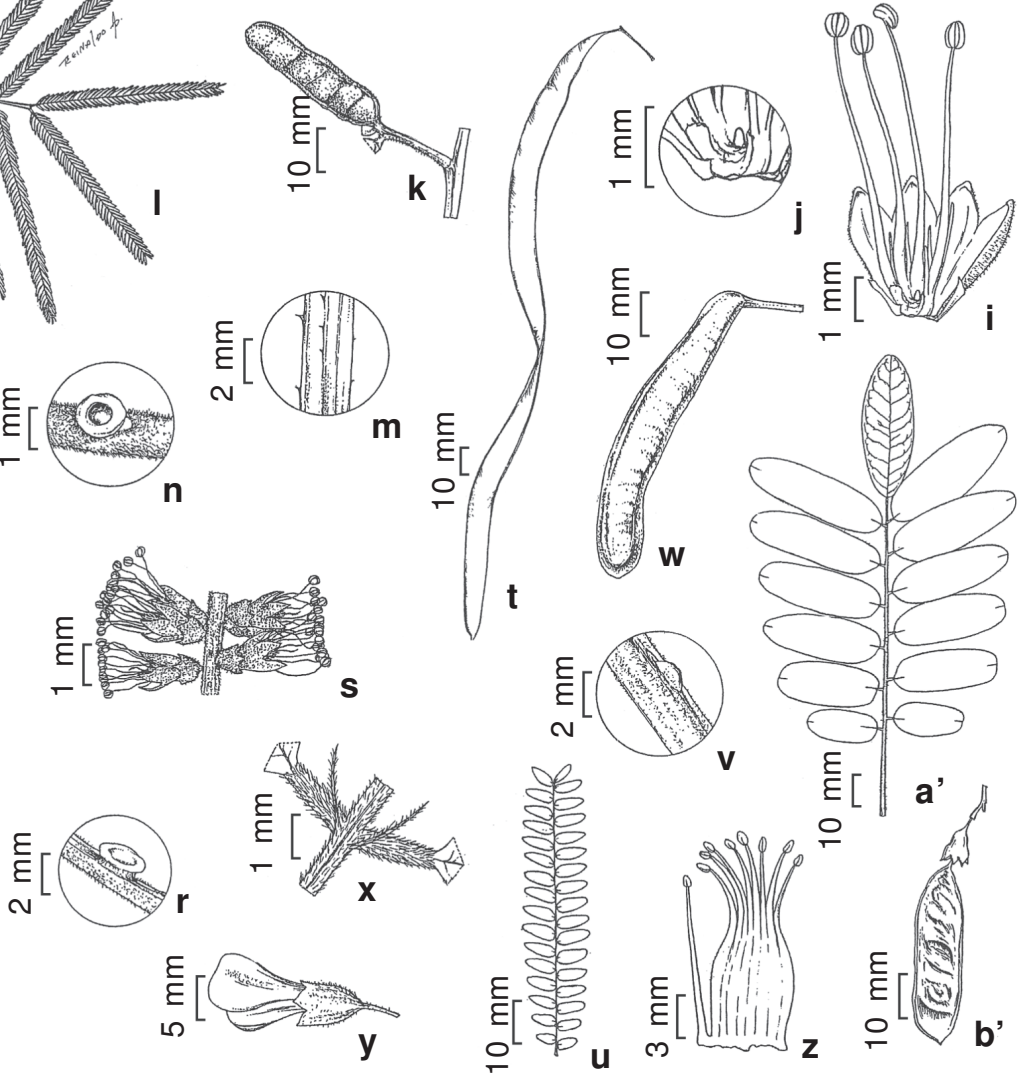

Figura 4 - a-b. Inga vera subsp. affinis (a Souza 214; b Lima 341) - a. flor; b. fruto. c-e. Inga vulpina (c-d Lima 211; e Lima 4066) - c. ramo com inflorescência; d. nectário; e. fruto. f-k. Mimosa scabrella (f-j Lima 376; k Lima 233) - f. ramo com inflorescência; g. indumento da raque foliar; h. indumento da face adaxial do foliólulo; i. flor andromonóica em corte longitudinal; j. detalhe do gineceu rudimentar; k. fruto. 1-p. Piptadenia gonoacantha (1-o Lima 264; p Lima 353) -1. folha; m. acúleo; n. nectário peciolar; o. flor em corte longitudinal; p. fruto. q-t. Pseudopiptadenia contorta (q-r, t Lima 379; s Lopes 37) - q. folha; r. nectário peciolar; s. detalhe da inflorescência; t. fruto. u-w. Stryphnodendron polyphyllum (Lima 347) - u. pina; v. nectário peciolar; w. fruto. x-z. Andira fraxinifolia (Mota 626): x. estipela; y. flor; z. androceu. a'-b'. Bowdichia virgilioides (Lima 402): a'. folha; b'. fruto.

Figure 4 - a-b. Inga vera subsp. affinis (a Souza 214; b Lima 341) - a. flower; b. fruit. c-e. Inga vulpina (c-d Lima 211; e Lima 4066) - c. flowering branch; d. nectary; e. fruit. f-k. Mimosa scabrella (f-j Lima 376; k Lima 233) - f. flowering branch; g. indument of the leaf raquis; $h$. indument adaxial surface leaflet; i. longitudinal section of the andromonoecious flower; j. detail of the gynoecium rudiment; k. fruit. 1-p. Piptadenia gonoacantha (1-o Lima 264; p Lima 353) - 1. leaf; m. aculeus; n. petiolar nectary; o. longitudinal section of the flower; p. fruit. q-t. Pseudopiptadenia contorta (q-r, t Lima 379; s Lopes 37) - q. leaf; r. petiolar nectary; s. detail of the inflorescence; t. fruit. u-w. Stryphnodendron polyphyllum (Lima 347) - u. pinna; v. petiolar nectary; w. fruit. x-z. Andira fraxinifolia (Mota 626) - x. stipels; y. flower; z. androecium. a'-b'. Bowdichia virgilioides (Lima 402) - a'. leaf; b'. fruit. 
eglandulares; ovário ca. 2 mm compr., glabro, estípite ca. 0,5 mm compr.; estilete ca. 2,5 mm compr., glabro. Legumes nucóides, 5-5,5 x 2,5-2,6 cm, retos, plano-compressos, ferrugíneo-tomentosos, margem inteira, ápice obtuso; sementes 8-11, ca. $7 \times 3 \mathrm{~mm}$, oblongas, castanhas, com sarcotesta.

Material examinado: Ouro Preto, estrada de Baixo, 12.XII.1990, fr., H.C. Lima et al. 4066 (OUPR); Mata do Manso, 19.IX.2004, fl., L.C.P. Lima \& F.C.P. Garcia 211 (VIC).

O nectário estipitado e os filetes róseos diferenciam esta das demais Mimosoideae arbóreas do PEI. Foi encontrada em floresta estacional altimontana. Floresceu em setembro e frutificou em novembro.

\section{Mimosa scabrella Benth., J. Bot. (Hooker) 4: 387. 1841. \\ Fig. $4 \mathrm{f}-\mathrm{k}$}

Avoretas ou árvores 5-12 m alt., ramos estriados, escabros. Estípulas ca. $4 \mathrm{~mm}$ compr., lanceoladas, caducas; pecíolo 2-4,5 cm compr., escabro; raque 3-4,5 cm compr., cilíndrica, escabra; nectários ausentes. Folhas bipinadas, 4 ou 5 pares de pinas; foliólulos 23 ou 34 pares, $7-8 \times$ ca. $2,1 \mathrm{~cm}$, opostos, oblongos, base oblíqua, ápice obtuso, ambas as faces revestidas por tricomas estrelados. Inflorescências capituliformes em fascículos axilares ou racemos terminais, homomórficas; pedúnculo 7-9 mm compr., escabro; raque globosa, diâmetro da inflorescência 5-6 mm (excluindo filetes). Flores tetrâmeras, actinomorfas, sésseis, andromonóicas; cálice $0,8-1 \mathrm{~mm}$ compr., campanulado, glabro externamente; corola gamopétala, ca. 3,5 mm compr., puberulenta externamente; estames 4, filetes amarelos, livres, 6-7 mm compr., glabros, anteras eglandulares, estaminódios 4; gineceu rudimentar. Craspédios, ca. $3 \times 0,9 \mathrm{~cm}$, retos, plano-compressos, muricados, margem sinuosa, ápice agudo; sementes 4, ca. $6 \times 4 \mathrm{~mm}$, obovadas, castanho-escuras.

Material examinado: Ouro Preto, estrada de Baixo, 22.VIII.2005, fl., L.C.P. Lima \& G. Pedreira 376 (VIC); trilha do Forno, 6.XII.2004, fr., L.C.P. Lima \& O. Magalhães 233 (VIC).

O ramo escabro, folíolo revestido por tricomas estrelados e o fruto muricado diferem esta das demais espécies de Mimosoideae do PEI. Foi coletada em floresta estacional altimontana, floresceu de agosto a outubro e frutificou setembro a dezembro.

24. Piptadenia gonoacantha (Mart.) J.F. Macbr., Contr. Gray Herb. 59: 17. $1919 . \quad$ Fig. 41-p

Árvores 10-20 m alt., ramos cilíndricos, cristados, tomentosos, acúleos não recurvos. Estípulas ca. 5 mm compr., linear-lanceoladas, caducas; pecíolo 2-
3,2 cm compr., tomentoso, acúleos não recurvos; raque $6,5-11 \mathrm{~cm}$ compr., canaliculada, tomentosa, acúleos não recurvos; nectários subsésseis, urceolados, no pecíolo, entre os pares de pinas distais e pares de foliólulos distais. Folhas bipinadas, pinas 7-10 pares; foliólulos (28-)32-50 pares, 5-6 $\times$ ca. $1 \mathrm{~cm}$, opostos, oblongos, base oblíqua, ápice agudo, ambas as faces glabrescentes. Inflorescências espiciformes, axilares, homomórficas; pedúnculo 4-10 mm compr., tomentoso; raque 5$6,5 \mathrm{~cm}$ compr. Flores pentâmeras, actinomorfas, sésseis; cálice 0,4-0,5 mm compr., campanulado, pubescente externamente; corola dialipétala, 1,2$1,5 \mathrm{~mm}$ compr., glabra externamente; estames 10 , filetes alvos, livres, 1,8-2 mm compr., glabros, anteras glandulares na antese; ovário $0,6-0,8 \mathrm{~mm}$ compr., glabro, estípite 0,8-1 mm compr., glabro; estilete 1-1,2 mm compr., glabro. Legumes, 12-17× 2,4-2,5 cm, retos, plano-compressos, puberulentos, margem inteira, ápice obtuso; sementes 12-15, 0,4$0,5 \times 0,4-0,5 \mathrm{~mm}$, arredondadas, castanho-escuras. Material examinado: Mariana, Cibrão, 20.I.2005, fl., L.C.P. Lima et al. 264 (VIC); 19.V.2005, fr., L.C.P. Lima \& M.P. Andrade 353 (VIC).

Os ramos armados e a corola dialipétala diferenciam esta das demais espécies de Mimosoideae do PEI. Na área de estudo, ocorre em área de florestas estacionais submontana e altimontana, floresceu de janeiro a fevereiro e frutificou de março a agosto.

25. Pseudopiptadenia contorta (DC.) G.P. Lewis \& M.P. Lima, Arch. Jard. Bot. Rio de Janeiro 30: 57. 1991.

Fig. 4 q-t

Árvores 18-20 m alt., ramos estriados, glabrescentes ou tomentosos. Estípulas não observadas, caducas; pecíolo 1,5-2,4 cm compr., glabrescente ou tomentoso; raque 9-12,7 cm compr., canaliculada, tomentosa; nectários sésseis, pateliformes, arredondados, no pecíolo, entre os pares de pinas distais e pares de foliólulos distais. Folhas bipinadas, 16-24 pares de pinas; foliólulos $37-52$ pares, $2,1-3,2 \times 0,5-0,6 \mathrm{~cm}$, opostos, lineares ou falcados, base oblíqua, ápice agudo ou subagudo, ambas as faces glabrescentes. Inflorescências espiciformes, axilares, homomórficas; pedúnculo 11,5 cm compr., tomentoso; raque 7-12 cm compr. Flores pentâmeras, actinomorfas, sésseis; cálice ca. $1 \mathrm{~mm}$ compr., campanulado, seríceo externamente; corola gamopétala, ca. $2 \mathrm{~mm}$ compr., serícea externamente; estames 10, filetes alvos, livres, ca. 4 mm compr., glabros, anteras glandulares na antese; ovário ca. $1 \mathrm{~mm}$ compr., viloso, estípite ca. $1 \mathrm{~mm}$ 
compr., glabro; estilete ca. $1 \mathrm{~mm}$ compr., glabro. Folículos 26,6-32 × 1,3-1,8 cm, contorcidos, planocompressos, glabros, margem inteira ou levemente sinuosa, ápice mucronulado; sementes 11-16, 1,72,6×ca. 1,1 cm, oblongo-ovadas, preto-esverdeadas. Material examinado: Mariana, Cibrão, 22.VIII.2005, fr., L.C.P. Lima \& J.C. Duelhi-Filho 379 (VIC).

Material adicional: Viçosa, Universidade Federal de Viçosa, Setor de Dendrologia, 13.X.2001, fl., M.M.M. Lopes et al. 37 (VIC).

Caracteriza-se pelo nectário pateliforme e o folículo contorcido. No PEI, foi coletada em floresta estacional submontana, floresceu de janeiro a fevereiro e frutificou de abril a setembro.

26. Stryphnodendron polyphyllum Mart., Flora 20(2, Beibl.): 117.1837. Fig. $4 \mathrm{u}-\mathrm{w}$ Árvores 5-6 m alt., ramos cilíndricos, glabros ou ferrugíneo-pubescentes. Estípulas não observadas, caducas; pecíolo 3,5-6 cm compr., pubescente ou tomentoso; raque 10-18 cm compr., canaliculada, pubescente ou tomentosa; nectários sésseis, verruciformes, no pecíolo e entre os pares de pinas distais. Folhas bipinadas, 12-16 pares de pinas; foliólulos 18-21 pares, 7-10 × 2,5-4 cm, alternos, oblongos, base oblíqua, ápice obtuso, ambas as faces seríceas. Inflorescências espiciformes, axilares, homomórficas; pedúnculo 1,5-1,8 cm compr., ferrugíneo-puberulento; raque 5-6 cm compr. Flores pentâmeras, actinomorfas, sésseis; cálice 0,8-1 mm compr., campanulado, glabro externamente; corola gamopétala, ca. $2 \mathrm{~mm}$ compr., glabra externamente; estames 10, filetes vináceos, livres, 2-3 mm compr., glabros, anteras glandulares na antese; ovário ca. $0,5 \mathrm{~mm}$ compr., glabro, estípite ca. $0,1 \mathrm{~mm}$ compr.; estilete ca. 3,2 mm compr., glabro. Legumes nucóides, 7-8 × 1-2 cm, retos, planocompressos, ferrugíneo-puberulentos, margem inteira, ápice obtuso; semente não observada.

Material examinado: Mariana, estrada do Cibrão, 7.XII.2004, fl., L.C.P. Lima \& M.E.F. Araújo 247 (VIC); trilha de Belém, 31.III.2005, fr., L.C.P. Lima et al. 347 (VIC).

Caracteriza-se pelos foliólulos alternos seríceos, filetes vináceos e o legume nucóide. No PEI, foi coletada em florestas estacionais submontana e montana, floresceu em dezembro e frutificou em março.

\section{Papilionoideae}

27. Andira fraxinifolia Benth., Comm. legum. gen.: 44. 1837.

Fig. 4 x-Z

Arbustos ou árvores 3-5 m alt., ramos estriados, tomentosos. Estípulas ca. 2 mm compr., triangulares, caducas; estipelas 3-4 mm compr., linear-lanceoladas, persistentes; pecíolo 2,5-5,4 cm compr., tomentoso ou viloso; raque 7-13,5 cm compr., canaliculada, tomentosa ou vilosa. Folhas 13-folioladas, imparipinadas; folíolos 9,5-12×3,2-3,6 cm, opostos, elípticos ou oblongos, base aguda, ápice cuspidado, face adaxial glabra, face abaxial tomentosa, venação broquidódroma, concolor. Inflorescências panículas, terminais, 2-4-floras; pedúnculo 1-1,7 cm compr., tomentoso ou viloso; raque 1,2-2,7 cm compr., tomentosa ou vilosa. Flores zigomorfas; pedicelo $3-$ 6 mm compr.; cálice ca. 1 cm compr., campanulado, 5-laciniado, lacínios 1-2 mm compr., puberulento externamente; corola roxa, estandarte ca. 1,6 cm compr., glabro externamente, alas ca. 1,6 cm compr., carenas ca. 1,6 cm compr.; androceu heterodínamo, estames 10, diadelfos $(9+1), 1,4-1,6 \mathrm{~cm}$ compr., anteras uniformes; ovário ca. $8 \mathrm{~mm}$ compr., seríceo, estípite ca. $3 \mathrm{~mm}$ compr.; estilete ca. $5 \mathrm{~mm}$ compr., curvado, seríceo; estigma terminal, glabro. Drupas, ca. 3,5× $1,5 \mathrm{~cm}$, oblíquas, glabrescentes, ápice cuspidado; semente 1, ca. $15 \times 8 \mathrm{~mm}$, globosa, amarela.

Material examinado: Mariana, Cibrão, 20.I.2005, L.C.P. Lima et al. 409 (VIC).

Material adicional: Mariana, Mina da Samitri, 7.IX.2000, fl., R.C. Mota \& P.L. Viana 626 (BHCB); Rio Vermelho, 19.V.1995, fr., s.c. (VIC 15716).

As folhas 13-folioladas e as estipelas persistentes são características vegetativas que diferem esta espécie das demais Papilionoideae do PEI. Na área de estudo, ocorre em florestas estacionais submontanas e montanas, porém não floresceu nem frutificou no período de estudo.

28. Bowdichia virgilioides Kunth in H.B.K., Nov. gen. sp. (ed. 4) 6:376.1823. Fig. 4 a'-b'

Árvores ca. $4 \mathrm{~m}$ alt., ramos cilíndricos, tomentosos. Estípulas 4-5 mm compr., ovadas, caducas; estipelas inconspícuas; pecíolo 1,8-2,8 cm compr., ferrugíneo-tomentoso; raque $5-8,7 \mathrm{~cm}$ compr., canaliculada, ferrugíneo-tomentosa. Folhas 9-13-folioladas, imparipinadas; folíolos 4-5,4×1,1$1,8 \mathrm{~cm}$, alternos, oblongos, base obtusa, ápice obtuso, face adaxial glabra, face abaxial alvo-serícea, venação broquidódroma, discolor. Inflorescências panículas, terminais, 10-16 flores por racemo; pedúnculo 1-1,5 cm compr., tomentoso; raque 4$5,5 \mathrm{~cm}$ compr., tomentosa. Flores zigomorfas; pedicelo ca. $5 \mathrm{~mm}$ compr.; cálice ca. $1 \mathrm{~cm}$ compr., campanulado, 5-laciniado, lacínios ca. $3 \mathrm{~mm}$ compr., pubescente externamente; corola azul; estandarte ca. 1,6 cm compr., glabro externamente, alas ca. $1,5 \mathrm{~cm}$ compr., carenas ca. $1,5 \mathrm{~cm}$ compr.; androceu heterodínamo, estames 10, dialistêmones, $8-10 \mathrm{~mm}$ compr., anteras uniformes; ovário ca. 4 mm compr., 
tomentoso estípite ca. $2 \mathrm{~mm}$ compr.; estilete ca. $2 \mathrm{~mm}$ compr., torcido, glabro; estigma terminal, glabro. Legumes samaróides, 4-5,5×0,9-1,1 cm, oblongos, glabros, ápice apiculado; sementes $1-3$, ca. $5 \times 3 \mathrm{~mm}$, obovadas, castanho-avermelhadas.

Material examinado: Mariana, estrada do Cibrão, 26.IX.2005, fl., L.C.P. Lima \& F.C.P. Garcia 388 (VIC); 16.XI.2005, fr., L.C.P. Lima \& M.E.F. Araújo 402 (VIC).

Os legumes samaróides e a corola azul destacam esta espécie no dossel da floresta estacional submontana do PEI. Floresceu em setembro e frutificou em novembro.

29. Dalbergia nigra (Vell.) Allemao ex Benth., J. Linn. Soc. Bot. 4(Suppl.): 36. $1860 . \quad$ Fig. 5 a-c

Árvores 3-18 m alt., ramos cilíndricos, glabros ou tomentosos. Estípulas não observadas, caducas; estipelas ausentes; pecíolo 0,6-1,2 cm compr., tomentoso; raque 4,5-9,5 cm compr., cilíndrica, tomentosa. Folhas 11-23-folioladas, imparipinadas; folíolos 1,2-2,3 ×0,4-0,6 cm, alternos, oblongos, base obtusa ou oblíqua, ápice retuso ou obtuso, face adaxial glabra, face abaxial serícea, venação broquidódroma, discolor. Inflorescências cimeiras, escorpióides, axilares, 6-10 flores por cimeira; pedúnculo 4-6 mm compr., viloso; raque 0,81,9 cm compr., viloso. Flores zigomorfas; pedicelo ca. $1 \mathrm{~mm}$ compr.; cálice ca. $7 \mathrm{~mm}$ compr., campanulado, 5-laciniado, lacínios 1,5-3 mm compr., pubescente externamente; corola branca, estandarte ca. $8 \mathrm{~mm}$ compr., glabro externamente, alas ca. $8 \mathrm{~mm}$ compr., carenas ca. $5 \mathrm{~mm}$ compr.; androceu heterodínamo, estames 10, monadelfos, 6-8 $\mathrm{mm}$ compr., anteras uniformes; ovário ca. $2 \mathrm{~mm}$ compr., viloso, estípite ca. $3 \mathrm{~mm}$ compr.; estilete ca. $1 \mathrm{~mm}$ compr., geniculado, glabro; estigma terminal, glabro. Sâmaras, 5-10, $5 \times 1,2-2,2 \mathrm{~cm}$, elípticas, glabras, região seminífera central, ápice agudo ou mucronulado; sementes 1 ou 2, ca. $6 \times 3,5 \mathrm{~mm}$, reniformes, castanhas.

Material examinado: Mariana, Cibrão, 23.VIII.2005, fr., L.C.P. Lima \& J.C. Duelhi-Filho 378 (VIC).

Material adicional: Ponte Nova, BR-356, próximo ao Bar Pimenteira, 23.X.2004, fl., L.C.P. Lima \& F.C.P. Garcia 214 (VIC).

Os folíolos oblongos de ápice retuso, estandarte glabro externamente e estilete geniculado são característicos desta espécie (Carvalho 1997). No PEI, foi coletada em florestas estacionais submontana e montana, não floresceu no período de estudo, mas frutificou de dezembro a outubro.
30. Dalbergia revoluta Ducke, Arch. Jard. Bot. Rio de Janeiro 4: 73. 1925.

Fig. 5 d-f

Árvores ca. $4 \mathrm{~m}$ alt., ramos estriados, glabros ou puberulentos. Estípulas não obervadas; estipelas ausentes; pecíolo 2,5-3 cm compr., tomentoso; raque 2,8-3,4 cm compr., estriada, tomentosa. Folhas 5-7-folioladas, imparipinadas; folíolos 4,2-7 × 1,8-2,7 cm, alternos, obovados, base aguda, ápice emarginado ou obcordado, ambas as faces glabras ou glabrescentes, margem revoluta, venação broquidódroma, discolor. Inflorescências não observadas. Flores não observadas. Sâmaras, 4,5-7 ×1,2-1,5 cm, elípticas ou oblongas, glabras, região seminífera central, ápice mucronulado ou apiculado; sementes $1-3$, ca. $7 \times 5 \mathrm{~mm}$, rômbicas, castanho-avermelhadas.

Material examinado: Mariana, estrada do Cibrão, 26.IX.2005, fr., L.C.P. Lima \& F.C.P. Garcia 386 (VIC).

Difere das demais espécies de Dalbergia do PEI pelos folíolos com margem revoluta e em menor número. Foi coletada em floresta estacional submontana, não floresceu no período de estudo, mas apresentou frutos de setembro a novembro.

31. Dalbergia villosa var. villosa (Benth.) Benth., J. Linn. Soc. Bot. 4(Suppl.): 38. $1860 . \quad$ Fig. 5 g-i Árvores 3-5 m alt., ramos cilíndricos, glabrescentes ou tomentosos. Estípulas 1-2 mm compr., oblongas, caducas; estipelas ausentes; pecíolo 5-7 mm compr., tomentoso; raque 3,4-4,7 cm compr., estriada, tomentosa. Folhas 15-17folioladas, imparipinadas; folíolos 1,8-2,5 ×0,5$1 \mathrm{~cm}$, alternos, elípticos ou obovados, base obtusa ou atenuada, ápice obtuso, face adaxial glabrescente ou serícea, face abaxial serícea, venação broquidódroma, discolor. Inflorescências panículas, axilares, 10-12 flores por racemo; pedúnculo ca. $5 \mathrm{~mm}$ compr., ferrugíneo-tomentoso; raque ca. $1 \mathrm{~cm}$ compr., ferrugíneo-tomentosa. Flores zigomorfas; pedicelo 1-2 mm compr.; cálice ca. 4 mm compr., campanulado, 5-laciniado, lacínios 1$2 \mathrm{~mm}$ compr., viloso externamente; corola alva, estandarte ca. $5 \mathrm{~mm}$ compr., tomentoso externamente, alas ca. $5 \mathrm{~mm}$ compr., carenas ca. $5 \mathrm{~mm}$ compr.; androceu heterodínamo, estames 9, monadelfos, 4$5 \mathrm{~mm}$ compr., anteras uniformes; ovário ca. $3 \mathrm{~mm}$ compr., viloso, estípite ca. $1 \mathrm{~mm}$ compr.; estilete ca. $1 \mathrm{~mm}$ compr., reto, glabro; estigma terminal, glabro. Sâmaras, 3-4,5×0,8-1 cm, elípticas, glabrescentes, região seminífera central, ápice mucronulado; semente 1 , ca. $7 \times 5 \mathrm{~mm}$, reniforme, castanha. 


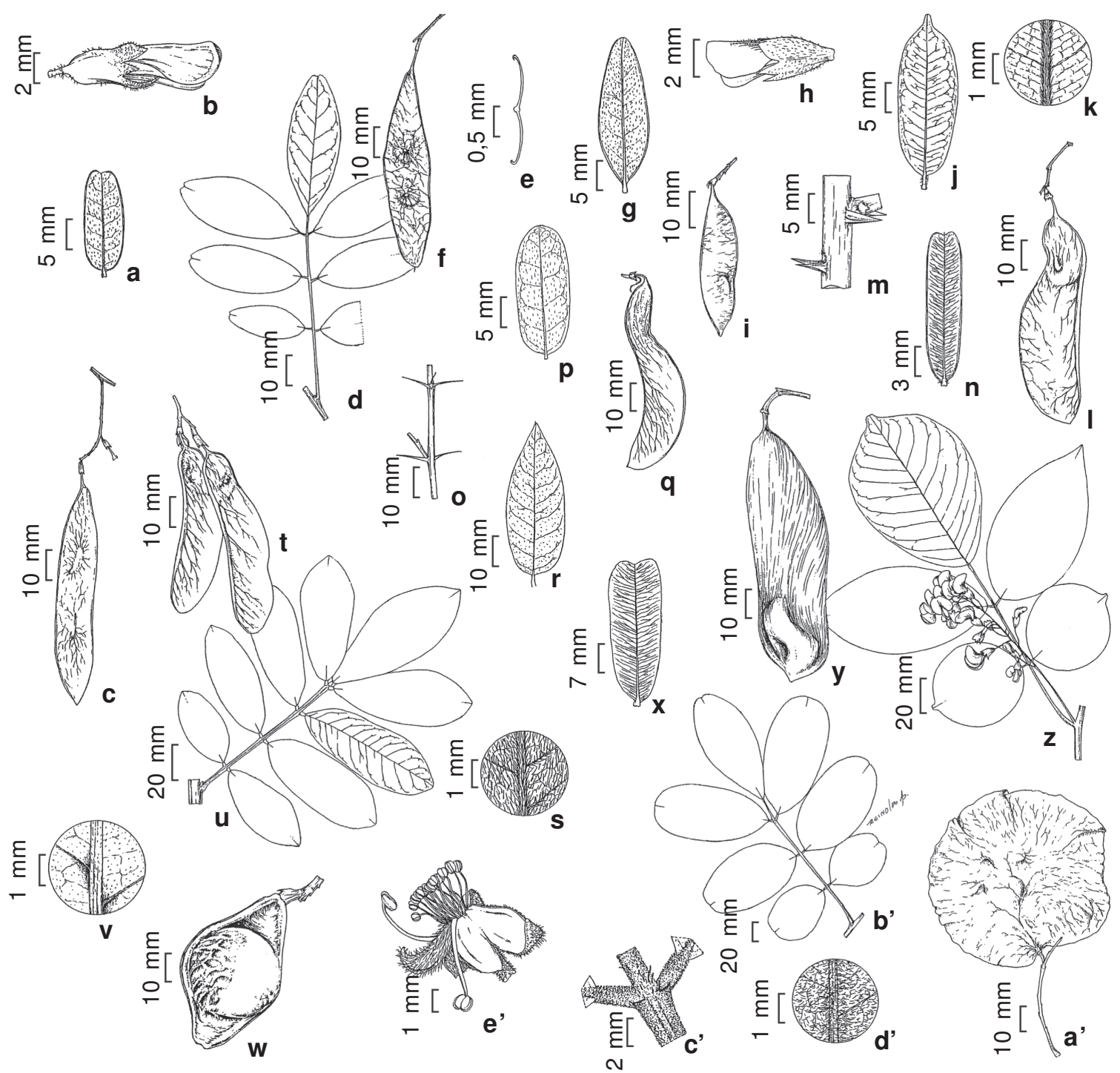

Figura 5 - a-c. Dalbergia nigra (a-b Lima 214; c Lima 378) - a. face abaxial do folíolo; b. flor; c. fruto. d-f. Dalbergia revoluta (Lima 386) - d. folha; e. corte transversal do folíolo; f. fruto. g-i. Dalbergia villosa var. villosa (g-h Lima 404; i Lima 280) - g. face abaxial do folíolo; h. flor; i. fruto. j-1. Machaerium brasiliense (Lima 370) - j. face abaxial do folíolo; k. indumento da face abaxial do folíolo; 1. fruto. m-n. Machaerium hirtum (Lima 408) - m. estípula; n. face adaxial do folíolo. o-q. Mahaerium nyctitans (o-p Lima 398; q Valente 589) - o. estípula; p. face abaxial do folíolo; q. fruto. r-t. Machaerium villosum (r-s Lima 227; t Lima 328) - r. folíolo; s. indumento da face abaxial do folíolo; t. frutos. u-w. Ormosia friburgensis (Lima 206) - u. folha; $\mathrm{v}$. indumento da face abaxial do folíolo; $\mathrm{w}$. fruto. $\mathrm{x}-\mathrm{y}$. Platypodium elegans (Lima 362) - $\mathrm{x}$. face abaxial do folíolo; y. fruto. z-a'. Pterocarpus rohrii (z Damázio s.n. OUPR 4528; a' Lima 387) - z. ramo com inflorescência; a'. fruto. b'-e'. Swartzia pilulifera (Lima 209) - b'. folha; c'. cicatriz da estipela; d'. indumento da face abaxial do folíolo; e'. flor.

Figure 5 - a-c. Dalbergia nigra (a-b Lima 214; c Lima 378) - a. abaxial surface of leaflet; b. flower; c. fruit. d-f. Dalbergia revoluta (Lima 386) - d. leaf; e. transverse section of the leaflet; f. fruit. g-i. Dalbergia villosa var. villosa (g-h Lima 404; i Lima 280) - g. abaxial surface of leaflet; h. flower; i. fruit. j-1. Machaerium brasiliense (Lima 370) - j. abaxial surface of leaflet; $\mathrm{k}$. indument of the leaflet abaxial surface; 1. fruit. m-n. Machaerium hirtum (Lima 408) - m. stipule; n. adaxial surface of leaflet. o-q. Mahaerium nyctitans (o-p Lima 398; q Valente 589) - o. stipule; p. abaxial surface of leaflet; q. fruit. r-t. Machaerium villosum (r-s Lima 227; $\mathrm{t}$ Lima 328) - r. leaflet; s. indument of the leaflet abaxial surface; t. fruits. u-w. Ormosia friburgensis (Lima 206) - u. leaf; v. indument of the leaflet abaxial surface; w. fruit. x-y. Platypodium elegans (Lima 362) - x. abaxial surface of leaflet; y. fruit. z-a'. Pterocarpus rohrii (z Damázio s.n. OUPR 4528; a' Lima 387) - z. flowering branch; a'. fruit. b’-e'. Swartzia pilulifera (Lima 209) - b'. leaf; c'. scars of stipels; d'. indument abaxial surface leafllet; e'. flower. 
Material selecionado: Mariana, trilha de Belém, 21.I.2005, fr., L.C.P. Lima et al. 280 (VIC); 17.V.2005, fl. L.C.P. Lima \& A. Casazza 404 (VIC); Ouro Preto, estrada para Fazenda do Manso, 15.I.1994, fl., S. Dias \& M.B. Roschel s.n. (OUPR 1347).

Os folíolos e o cálice vilosos diferenciam esta das demais espécies de Dalbergia da área de estudo. No PEI, ocorre em florestas estacionais submontana, montana e altimontana, floresceu em novembro e frutificou em janeiro.

32. Machaerium brasiliense Vogel, Linnaea 11: 185. 1837.

Fig. $5 \mathrm{j}-1$

Árvores 2-4 m alt., ramos cilíndricos, pubescentes ou tomentosos. Estípulas não observadas, caducas; estipelas ausentes; pecíolo 1,6-2,4 cm compr., pubescente ou ferrugíneotomentoso; raque 4-8,2 cm compr., cilíndrica, pubescente ou ferrugíneo-tomentosa. Folhas 9-11folioladas, imparipinadas; folíolos 2,5-6 ×0,9$1,7 \mathrm{~cm}$, alternos, elípticos, base obtusa, ápice acuminado, face adaxial glabra, face abaxial glabrescente ou ferrugíneo-velutina, venação broquidódroma, concolor. Inflorescências racemosas, axilares, 8-12-floras; pedúnculo 1,8$2 \mathrm{~cm}$ compr., tomentoso; raque $2-3 \mathrm{~cm}$ compr., tomentosa. Flores zigomorfas; pedicelo ca. $1 \mathrm{~mm}$ compr.; cálice ca. $4 \mathrm{~mm}$ compr., campanulado, 5laciniado, lacínios ca. $1 \mathrm{~mm}$ compr., tomentoso externamente; corola creme-esverdeada; estandarte ca. $8 \mathrm{~mm}$ compr., seríceo externamente, alas ca. 7,5 mm compr., carenas ca. $7 \mathrm{~mm}$ compr.; androceu heterodínamo, estames 10, diadelfos (9+1), 6-7 mm compr., anteras uniformes; ovário ca. $3 \mathrm{~mm}$ compr., viloso, estípite ca. $1,5 \mathrm{~mm}$ compr.; estilete ca. $3 \mathrm{~mm}$ compr., curvado, glabro; estigma terminal, glabro. Sâmaras, 6,8-8,4 cm compr., falciformes, glabrescentes, região seminífera basal, ápice obtuso ou apiculado; semente 1 , ca. $12 \times 8 \mathrm{~mm}$, reniforme, enegrecida.

Material examinado: Mariana, trilha de Belém, 17.VI.2005, fr., L.C.P. Lima et al. 370 (VIC).

Material adicional: Viçosa, ESAU, 10.X.1933, fl., J.G. Kuhlmam s.n. (VIC 2221).

Machaerium brasiliense diferencia-se das demais Papilionoideae arbóreas do PEI pelos folíolos de ápice acuminado e as sâmaras falciformes. No PEI, foi coletada em florestas estacionais montana e submontana, não foram observadas flores no período de estudo, mas frutos em junho.
33. Machaerium hirtum (Vell.) Stellfeld, Tribuna Farm. 12: 132. 1944. Fig. $5 \mathrm{~m}-\mathrm{n}$ Machaerium angustifolium Vogel, Linnea 11: 193. 1837.

Árvores ca. $12 \mathrm{~m}$ alt., ramos cilíndricos, puberulentos, armados. Estípulas 3-5 mm compr., aculeadas, acúleos retilíneos; estipelas ausentes; pecíolo 4-8 mm compr., pubescente ou ferrugíneotomentoso; raque 5,5-8 cm compr., cilíndrica, pubescente ou ferrugíneo-tomentosa. Folhas (29-) 37-45-folioladas, imparipinadas; folíolos 9-16×2$4 \mathrm{~mm}$, alternos ou subopostos, estreito-oblongos, base obtusa, ápice mucronado, face adaxial glabrescente, face abaxial serícea, venação craspedódroma, concolor. Inflorescências paniculadas, axilares ou terminais, 8-15 flores por racemo; pedúnculo 3-4 mm compr., ferrugíneoseríceo; raque 0,5-3,5 cm compr., ferrugíneoseríceo. Flores zigomorfas; pedicelo 1-2 mm compr.; cálice ca. 6 mm compr., campanulado, 5laciniado, lacínios ca. $1 \mathrm{~mm}$ compr., puberulento externamente; corola roxa, estandarte ca. $8 \mathrm{~mm}$ compr., velutino externamente, alas ca. $8 \mathrm{~mm}$ compr., carenas ca. $7 \mathrm{~mm}$ compr.; androceu heterodínamo, estames 10, monadelfos, 7-9 mm compr., anteras uniformes; ovário ca. $5 \mathrm{~mm}$ compr., velutino, estípite ca. $2 \mathrm{~mm}$ compr.; estilete ca. $2 \mathrm{~mm}$ compr., curvado, glabro; estigma terminal, glabro. Sâmaras, 5,5-6,5 cm compr., subfalcadas, pubescentes, região seminífera basal, ápice agudo; semente 1 , ca. $12 \times 8 \mathrm{~mm}$, reniforme, enegrecida. Material examinado: Ouro Preto, estrada do Cibrão, 16.VI.2005, L.C.P. Lima \& F.C.P. Garcia 408 (VIC). Material adicional: Barroso, Mata do Baú, 3.I.2002, fl., L.C.S. Assis 378 (VIC); Juiz de Fora, V.1993, fr., R.G. Silveira \& M.L.G. Lisboa s.n. (VIC 14345).

Assemelha-se a M. aculeatum Radii, da qual se diferencia por apresentar hábito arbóreo e estípulas aculeadas retilíneas (Mendonça-Filho 2002). Em geral, são identificadas de forma incorreta (e.g., Pedralli et al. 1997). Hoehne (1941) considerou $M$. angustifolium Vogel sinônimo de $M$. aculeatum e Lima (1995) considerou $M$. angustifolium sinônimo de M. hirtum. Estudos recentes baseados em características morfológicas e número de cromossomos (Mendonça-Filho et al. 2002) confirmam a separação de $M$. aculeatum e $M$. hirtum estabelecendo de forma consistente a delimitação taxonômica dessas espécies. No PEI, foi coletada em floresta estacional submontana, não florescendo nem frutificando no período de estudo. 
34. Machaerium nyctitans (Vell.) Benth., Comm. legum. gen. 34. 1837.

Fig. 5 o-q

Árvores 3-6 m alt., ramos cilíndricos, ferrugíneotomentosos, armados. Estípulas 0,9-1,1 cm compr., aculeadas, acúleos retilíneos; estipelas ausentes; pecíolo 0,4-2,7 cm compr., ferrugíneo-tomentoso; raque 5-8 cm compr., estriada, tomentosa. Folhas 13-21-folioladas, imparipinadas; folíolos 1,3-2,3× 0,5-1 cm, alternos ou subopostos, oblongos, base obtusa, ápice obtuso, ambas as faces seríceas, venação broquidódroma, discolor. Inflorescências paniculadas, terminais, 16-18 flores por racemo; pedúnculo 4-8 mm compr., ferrugíneo-pubescente; raque 1,4-1,6 cm compr., ferrugíneo-pubescente. Flores zigomorfas; pedicelo ca. $1 \mathrm{~mm}$ compr.; cálice ca. $5 \mathrm{~mm}$ compr., campanulado, 5-laciniado, lacínios 1,5-2 mm compr., ferrugíneo-seríceo externamente; corola vinácea, estandarte ca. 9 mm compr., ferrugíneoseríceo externamente, alas ca. $8 \mathrm{~mm}$ compr., carenas ca. $7 \mathrm{~mm}$ compr.; androceu heterodínamo, estames 10, monadelfos, 6-8 mm compr., anteras uniformes; ovário ca. $3 \mathrm{~mm}$ compr., seríceo, estípite ca. $3 \mathrm{~mm}$ compr.; estilete ca. $1 \mathrm{~mm}$ compr., reto, glabro; estigma terminal, glabro. Sâmaras, 5,5-6 cm compr., falcadas, glabras, região seminífera basal, ápice obtuso; semente 1 , ca. $6 \times 3 \mathrm{~mm}$, oblonga-reniforme, castanho-escura.

Material examinado: Mariana, trilha de Belém, 17.VI.2005, L.C.P. Lima et al. 399 (VIC); Ouro Preto, estrada de Baixo, 27.IX.2005, L.C.P. Lima \& F.C.P. Garcia 398 (VIC).

Material adicional: Viçosa, Reserva Florestal Mata do Paraíso, fl., 11.VI.2005, I.M.C. Rodrigues \& L. Basílio 47 (VIC); 24.X.2005, fr., G. Valente \& L. Basílio 589 (VIC).

Os ramos armados e os acúleos retilíneos facilitam o reconhecimento desta espécie no PEI. $\mathrm{Na}$ área de estudo, ocorre em florestas estacionais montana e altimontana, porém não floresceu nem frutificou no período de estudo.

35. Machaerium villosum Vogel, Linnaea 11: 189. 1837.

Fig. $5 \mathrm{r}-\mathrm{t}$

Árvores 7-12 m alt., ramos cilíndricos, alvovilosos. Estípulas não observadas, caducas; estipelas ausentes; pecíolo 3,1-5,1 cm compr., alvoviloso; raque 8-15 cm compr., cilíndrica, alvo-vilosa. Folha 15-23-foliolada, imparipinada; folíolos 5,4$8,2 \times 1,4-3 \mathrm{~cm}$, alternos ou subopostos, elípticos, oblongos ou ovado-lanceolados, base atenuada ou obtusa, ápice agudo, ambas as faces alvo-vilosas, venação broquidódroma, discolor. Inflorescências paniculadas, axilares, 10 flores por racemo; pedúnculo 1,1-3 cm compr., alvo-viloso; raque 4,5-6 cm compr., alvo-vilosa. Flores zigomorfas, pediceladas, pedicelo ca. $1 \mathrm{~mm}$ compr.; cálice ca. 5 mm compr., campanulado, 5-laciniado, lacínios 2$4 \mathrm{~mm}$ compr., seríceo externamente; corola roxa, estandarte ca. $9 \mathrm{~mm}$ compr., seríceo externamente, alas ca. $7 \mathrm{~mm}$ compr., carenas ca. $8 \mathrm{~mm}$ compr.; androceu heterodínamo, estames 10 , monadelfos, 6-7 mm compr., anteras uniformes; ovário ca. $3 \mathrm{~mm}$ compr., viloso, estípite ca. $3 \mathrm{~mm}$ compr.; estilete ca. $1 \mathrm{~mm}$ compr., geniculado, glabro; estigma terminal, glabro. Sâmaras oblongas, ferrugíneoseríceas, região seminífera basal, 5-6 cm compr., região seminífera 0,9-1 cm larg., asa 1,1-1,4 cm larg., ápice obtuso; semente 1 , ca. $9 \times 6 \mathrm{~mm}$, reniforme, castanho-escura.

Material examinado: Mariana, trilha de Belém, 31.II.2005, fr., L.C.P. Lima et al. 328 (VIC). Ouro Preto, trilha da Alcan, 24.X.2004, fl., L.C.P. Lima \& F.C.P. Garcia 227 (VIC).

Caracteriza-se pelos ramos alvo-vilosos e as sâmaras oblongas. No PEI, foi coletada em florestas estacionais montana e altimontana, floresceu de outubro a dezembro e frutificou de novembro a fevereiro.

36. Ormosia friburgensis Taub. ex Harms, Feddes Repert. Spec. Nov. Regni Veg. 19: 290. 1924.

Fig. 5 u-w

Árvores $15 \mathrm{~m}$ alt., ramos estriados, glabros. Estípulas não observadas, caducas; estipelas ausentes; pecíolo 1,5-2,5 cm compr., ferrugíneotomentoso; raque 5,8-7,2 cm compr., estriada, ferrugíneo-tomentosa. Folhas 7-9-folioladas, imparipinadas; folíolos 7,5-10×2,5-4,4 cm, opostos, elíptico-oblongos ou obovados, base aguda, ápice acuminado, face adaxial glabra, face abaxial pubescente, venação broquidódroma, concolor. Inflorescências não observadas. Flores não observadas. Legumes, 4,5-8 ×3,2-4 cm, oblíquos, ferrugíneo-tomentosos, ápice agudo; semente 12 , ca. $2,4 \times 1,8 \mathrm{~cm}$, globosas, vermelho-amareladas ou vermelho-alaranjadas.

Material examinado: Ouro Preto, mata próxima a estrada da Torre, 3.VIII.2004, fr., L.C.P. Lima et al. 206 (VIC); 23.VIII.2005, fr., L.C.P. Lima et al. 396 (VIC).

As sementes globosas vermelho-amareladas ou vermelho-alaranjadas facilitam o reconhecimento desta espécie na floresta estacional altimontana do PEI. Rudd (1965) citou está espécie apenas para São Paulo e Rio de Janeiro, sendo este seu primeiro registro para Minas Gerais. Não foram observadas flores no período de estudo, mas frutos em agosto. 
37. Platypodium elegans Vogel, Linnaea 11: 420. 1837. Fig. $5 x-y$

Árvores 9-12 m alt., ramos canaliculados, pubérulos. Estípulas não observadas, caducas; estipelas ausentes; pecíolo 0,8-1,1 cm compr., pubérulo; raque 7,6-9 $\mathrm{cm}$ compr., canaliculada, pubérula. Folhas 13-17-folioladas, imparipinadas; folíolos 3,6-3,8 × 1,1-1,3 cm, opostos ou alternos, oblongos, base aguda, ápice emarginado, face adaxial glabra, face abaxial tomentosa, venação camptódroma, concolor. Inflorescências panículas, terminais e axilares, 4-6 flores por racemo; pedúnculo 2-3 cm compr., tomentoso; raque 1,5-1,8 cm compr., tomentosa. Flores zigomorfas, pediceladas, pedicelo ca. 1,6 cm compr.; cálice ca. 1 cm compr., campanulado, 5-laciniado, lacínios ca. $4 \mathrm{~mm}$ compr., glabro ou puberulento externamente; corola amarela; estandarte ca. 1,8 cm compr., glabro externamente, alas ca. 1,6 cm compr., carenas ca. 1,3 cm compr.; androceu heterodínamo, estames 10, diadelfos $(5+5)$, 1-1,2 cm compr., anteras uniformes; ovário ca. $6 \mathrm{~mm}$ compr., seríceo, estípite ca. $5 \mathrm{~mm}$ compr.; estilete ca. $4 \mathrm{~mm}$ compr., curvado, glabro; estigma terminal, glabro. Sâmaras, 8-9 cm compr., oblongas, glabrescentes, região seminífera apical, ápice obtuso; semente 1 , ca. $1,5 \times 0,8 \mathrm{~cm}$, oblonga, castanha.

Material examinado: Mariana, Cibrão, 16.VI.2005, fr., L.C.P. Lima et al. 362 (VIC); 16.XI.2005, fl., L.C.P. Lima \& M.E.F. Araújo 401 (VIC).

$\mathrm{O}$ folíolo de ápice emarginado e venação camptódroma e a sâmara com região seminífera apical caracterizam esta espécie. No PEI, foi coletada em floresta estacional submontana, floresceu em novembro e frutificou em junho.

38. Pterocarpus rohrii Vahl, Symb. bot. 2: 79-80. 1791.

Fig. $5 \mathrm{z}-\mathrm{a}$

Árvores ca. $20 \mathrm{~m}$ alt., ramos estriados, glabros ou puberulentos. Estípulas não observadas, caducas; estipelas ausentes; pecíolo 1,5-3 cm compr., glabro ou puberulento; raque $5-8 \mathrm{~cm}$ compr., canaliculada, glabra ou puberulenta. Folhas 5-7-folioladas, imparipinadas; folíolos 5,8-12 ×3$6,7 \mathrm{~cm}$, alternos, oblongos, elípticos ou obovados, base obtusa ou aguda, ápice obtuso ou acuminado, face adaxial glabra, face abaxial glabrescente ou pubescente, venação broquidódroma, concolor. Inflorescências racemosas, axilares, ca. 45-floras; pedúnculo ca. 3,6 cm compr., tomentoso; raque ca. $7 \mathrm{~cm}$ compr., tomentosa. Flores zigomorfas, pediceladas, pedicelo ca. $8 \mathrm{~mm}$ compr.; cálice ca. $6 \mathrm{~mm}$ compr., campanulado, 5-laciniado, tubo ca.
4 mm compr., lacínios ca. 2 mm compr., puberulento externamente; corola amarela, estandarte ca. $1,6 \mathrm{~cm}$ compr., glabro externamente, alas ca. 1,3 cm compr., carena ca. 1,3 cm compr.; androceu heterodínamo, estames 10, monadelfos, 7-9 mm compr., anteras uniformes; ovário ca. 3 mm compr., viloso, séssil; estilete ca. $1 \mathrm{~cm}$ compr., reto, glabro; estigma terminal, glabro. Sâmaras, 4,8-7,2 × 5,5-6,7 cm, orbiculares, glabras ou glabrescentes, região seminífera central, ápice obtuso; semente 1, ca. 20 $\times 7 \mathrm{~mm}$, oblonga-reniforme, castanho-clara.

Material examinado: Mariana, estrada do Cibrão, 26.IX.2005, fr., L.C.P. Lima \& F.C.P. Garcia 387 (VIC). Ouro Preto, base do Itacolomi, s.d., fl., L. Damázio s.n. (OUPR 4528).

Caracteriza-se pelas sâmaras orbiculares com região seminífera central. No PEI, foi coletada em floresta estacional submontana, não foram observadas flores, mas apresentou frutos em setembro.

39. Swartzia pilulifera Benth., J. Bot. (Hooker) 2: 90. 1840.

Fig. 5 b'-e'

Árvores 2-6 m alt., ramos canaliculados, glabrescentes, ferrugíneo-tomentosos. Estípulas 5$6 \mathrm{~mm}$ compr., lanceoladas, caducas; estipelas 1-2 $\mathrm{mm}$ compr., triangulares, caducas; pecíolo $2-3 \mathrm{~cm}$ compr., ferrugíneo-tomentoso; raque 3,5-9,5 cm compr., marginada, ferrugíneo-tomentosa. Folhas 5-7-folioladas, imparipinadas; folíolos 5,5-20 ×2$6,5 \mathrm{~cm}$, opostos ou subopostos, elípticos, oblongos ou obovados, base aguda ou obtusa, ápice agudo, obtuso ou retuso, ambas as faces ferrugíneotomentosas, venação broquidódroma, concolor. Inflorescências racemosas, axilares, 16-32-floras; pedúnculo 0,5-1 cm compr., ferrugíneo-tomentoso; raque 5-8 cm compr., ferrugíneo-tomentosa. Flores apétalas, pediceladas, pedicelo 3-6 $\mathrm{mm}$ compr.; cálice 5-6 mm compr., inteiro no botão, 4segmentado na antese, ferrugíneo-tomentoso externamente; corola ausente; androceu heterodínamo, estames 29-32, dialistêmones, 2 ou 3 estames maiores ca. 5 mm compr., 27-29 estames menores ca. 2 mm compr., anteras uniformes; ovário ca. 2 mm compr., seríceo, estípite ca. 2 mm compr.; estilete ca. 0,5 mm compr., geniculado, glabro; estigma terminal, glabro. Legumes, ca. $2 \times 1,5 \mathrm{~cm}$, largo-ovados ou elípticos, ferrugíneo-tomentosos ou glabrescentes, ápice obtuso; semente 1, ca. 1,5 $\times 0,8 \mathrm{~cm}$, obovada, preta, arilo alvo.

Material selecionado: Ouro Preto, estrada da Torre, 18.IX.2004, fl., L.C.P. Lima et al. 209 (VIC); 24.X.2004, fl. e fr., L.C.P. Lima \& F.C.P. Garcia 216 (VIC). 
A ausência de corola e os estames dialistêmones diferem esta espécie das demais Papilionoideae arbóreas do PEI. O comprimento do pecíolo e da raque foliar não conferem com a chave proposta por Mansano \& Tozzi (1999), mas abrangem a amplitude morfológica descrita por Cowan (1967). No PEI, foi coletada em áreas de floresta estacional altimontana, floresceu de julho a agosto e frutificou de outubro a fevereiro.

\section{Agradecimentos}

Ao CNPq, a bolsa de mestrado concedida à primeira autora; ao IEF, pela estrututa física concedida; a Mário E.F. Araújo, a ajuda no trabalho de campo; aos curadores dos Herbários OUPR e BHCB, o empréstimo de material botânico; a Vidal F. Mansano, a confirmação de Swartzia; e a Reinaldo Pinto, as ilustrações botânicas.

\section{Referências}

Almeida, G.S.S. 2008. Asteraceae Dumort. nos campos rupestres do Parque Estadual do Itacolomi, Minas Gerais, Brasil. Tese de Doutorado. Universidade Federal de Viçosa. 365p.

Alves, R.J.V. 1990. The Orchidaceae of the Itacolomi State Park in Minas Gerais, Brazil. Acta Botanica Brasilica 4: 65-72.

Araújo, R.S. 2008. Bignoniaceae Juss. do Parque Estadual do Itacolomi, Minas Gerais, Brasil: florística, similaridade e distribuição geográfica. Dissertação de Mestrado. Universidade Federal de Viçosa, Viçosa. 67p.

Barneby, R.C. \& Grimes, J. 1996. Silk tree, guanacaste, monkey's earring: a generic system for the synandrous Mimosaceae of the Americas. Memoirs of the New York Botanical Garden 74: 1-292.

Barroso, G.M.; Peixoto, A.L.; Costa, C.G.; Ichaso, C.L.F.; Guimarães, E.F. \& Lima, H.C. 1991. Sistemática das angiospermas do Brasil. Vol 2. Imprensa Universitária, Universidade Federal de Viçosa, Viçosa. Pp. 15-100.

Barroso, G.M.; Morim, M.P.; Peixoto, A.L. \& Ichaso, C.L.F. 1999. Frutos e sementes: morfologia aplicada a sistemática de dicotiledôneas. Imprensa Universitária, Universidade Federal de Viçosa, Viçosa. 443p.

Batista, J.A.N.; Bianchetti, L.B.; Nogueira, R.E.; Pellizzaro, K.F. \& Ferreira, F.E. 2004. The genus Habenaria (Orchidaceae) in the Itacolomi State Park, Minas Gerais, Brazil. Sitientibus série Ciências Biológicas 4: 25-36.

Bortoluzzi, R.L.C. 2004. A subfamília Caesalpinioideae (Leguminosae) no estado de Santa Catarina, Brasil.
Tese de Doutorado. Universidade Federal do Rio de Grande do Sul, Porto Alegre. 319p.

Bortoluzzi, R.L.C.; Garcia, F.C.P.; Carvalho-Okano, R.M. \& Tozzi, A.M.G.A. 2003. Leguminosae, Papilionoideae no Parque Estadual do Rio Doce, Minas Gerais, Brasil. I: trepadeiras e subarbustos. Iheringia, Série Botânica 58: 25-60.

Bortoluzzi, R.L.C.; Carvalho-Okano, R.M.; Garcia, F.C.P. \& Tozzi, A.M.G.A. 2004. Leguminosae, Papilionoideae no Parque Estadual do Rio Doce, Minas Gerais, Brasil. II: árvores e arbustos escandentes. Acta Botanica Brasilica 18: 49-72.

Bosquetti, L. de B. 2004. Caesalpinioideae (Leguminosae) no Parque Estadual do Rio Doce, Minas Gerais, Brasil. Dissertação de Mestrado. Universidade Federal de Viçosa, Viçosa. 86p.

Carvalho, A.M. 1997. A synopsis of the genus Dalbergia (Fabaceae: Dalbergieae) in Brazil. Brittonia 49: 87-109.

Coser, T.S. 2008. Bromeliaceae Juss. dos campos rupestres do Parque Estadual do Itacolomi, Minas Gerais, Brasil: florística e aspectos fenológicos. Dissertação de Mestrado. Universidade Federal de Viçosa, Viçosa. 84p.

Cowan, R.S. 1967. Swartzia (Leguminosae, Caesalpinioideae, Swartziaeae). Flora Neotropica 1: 1-228.

Dutra, V. F.; Messias, M.C.T.B. \& Garcia, F.C.P. 2006. Papilionoideae (Leguminosae) nos campos ferruginosos do Parque Estadual do Itacolomi, Minas Gerais, Brasil: Florística e fenologia. Revista Brasileira de Botânica 28: 493-504.

Dutra, V.F.; Garcia, F.C.P.; Lima, H.C. \& Queiroz, L.P. 2008a. Diversidade florística de Leguminosae Adans. em áreas de campos rupestres. Megadiversidade 4: 145-152.

Dutra, V.F.; Garcia, F.C.P. \& Lima, H.C. 2008 b. Caesalpinioideae (Leguminosae) nos campos rupestres do Parque Estadual do Itacolomi, MG, Brasil. Acta Botanica Brasilica 22: 547-558.

Dutra, V.F.; Garcia, F.C.P. \& Lima, H.C. 2008c. Mimosoideae (Leguminosae) nos campos rupestres do Parque Estadual do Itacolomi, Minas Gerais, Brasil. Rodriguésia 59: 573-585.

Dutra, V.F.; Garcia, F.C.P. \& Lima, H.C. 2009. Papilionoideae (Leguminosae) nos campos rupestres do Parque Estadual do Itacolomi, MG, Brasil. Acta Botanica Brasilica 23: 145-159.

Dwyer, J.D. 1951. The Central American, West Indian and S. American species of Copaifera (Caesalpiniaceae). Brittonia 7: 143-172.

Dwyer, J.D. 1957. The American genus Sclerolobium Vogel (Caesalpiniecae). Lloydia 20: 67-118.

Giulietti, A.M.; Harley, R.M.; Queiroz, L.P.; Wanderley, M.G.L. \& Berg, C. 2005. Biodiversity and conservation of plants in Brazil. Conservation Biology 19: 632-639. 
Harris, J.G. \& Harris, M.W. 1994. Plant identification terminology: an ilustred glossary. Spring Lake Publishing, Utah. 198p.

Hoehne, F.C. 1941. Leguminosas-Papilionadas: gêneros Machaerium e Paramachaerium. Flora Brasilica 25: 1-100.

Irwin, H.S. \& Barneby, R.C. 1982. The American Cassiinae - A synoptical revision of Leguminosae - Tribe Cassieae subtribe Cassiinae in the New World. Memoirs of the New York Botanical Garden 35: 1-918.

Lewis, G.; Schire, B.; Mackinder, B. \& Lock, M. 2005. Legumes of the World. Royal Botanic Garden, Kew. $577 \mathrm{p}$.

Lima, H.C. 1995. Leguminosas da Flora Fluminensis J.M. da C. Vellozo - lista atualizada das espécies arbóreas. Acta Botanica Brasilica 9: 123-146.

Lima. H.C. 2000. Leguminosas arbóreas da Mata Atlântica - uma análise da riqueza, padrões de distribuição geográfica e similaridades florísticas em remanescentes florestais do estado do Rio de Janeiro. Tese de Doutorado. Universidade Federal do Rio de Janeiro, Rio de Janeiro. 122p.

Lima, H.C.; Correia, C.M.B. \& Farias, D.S. 1994. Leguminosae. In: Lima, M.P.M. \& Guedes-Bruni, R.R. (orgs.). Reserva Ecológica de Macaé de Cima, Nova Friburgo, RJ: aspectos florísticos das espécies vasculares. Vol. 1. Jardim Botânico do Rio de Janeiro, Rio de Janeiro. Pp. 167-228.

Lima, L.C.P.; Garcia, F.C.P. \& Sartori, A.L.B. 2007. Leguminosae Adans. nas florestas estacionais do Parque Estadual do Itacolomi, Minas Gerais, Brasil: Ervas, arbustos, subarbustos, lianas e trepadeiras. Rodriguésia 58: 331-358.

Mansano, V.F. \& Tozzi, A.M.G.A. 1999. The taxonomy of some Swartzieae (Leguminosae, Subfam. Papilionoideae) from southeastern Brazil. Brittonia 51: 149-158.

Martins, C.S. 2000. Caracterização física e fitogeográfica de Minas Gerais. In: Mendonça, M.P. \& Lins, L.V. (eds.). Lista vermelha das espécies ameaçadas de extinção da Flora de Minas Gerais. Fundação Biodiversitas, ZooBotânica, Belo-Horizonte. Pp. 35-43.

Mendonça, R.C.; Felfili, J.M.; Walter, B.M.T.; Silva Jr., M.C.; Rezende, A.V.; Filgueiras, T.S. \& Nogueira, P.E. 1998. Flora vascular do cerrado. In: Sano, S.M. \& Almeida, S.P. (eds.). Cerrado: ambiente e flora. Embrapa-CPAC, Planaltina. Pp. 289-539.

Mendonça-Filho, C.V. 1996. Braúna, angico, jacarandá e outras leguminosas de Mata Atlântica: Estação Biológica de Caratinga, Minas Gerais. Fundação Biodiversitas, Belo Horizonte. 100p.

Mendonça-Filho, C.V. 2002. Citotaxonomia de Machaerium Pers. e revisão taxonômica de Machaerium sect. Oblonga (Benth.) Taub. (Leguminosae-Papilionoideae).
Tese de Doutorado da Universidade Estadual de Campinas, Campinas. 208p.

Mendonça-Filho, C.V.; Forni-Martins, E.R. \& Tozzi, A.M.G.A. 2002. New cromosome counts in Neotropical Machaerium Pers. Species (Fabaceae) and their taxonomic significance. Caryologia 55: 111-114.

Messias, M.C.T.B.; Dias, S.J.L.; Roschel, M.B.; Souza, H.C.; Silva, J.L. \& Matos, A.V.M. 1997. Levantamento florístico das matas e distribuição de algumas espécies endêmicas da região na área do Parque do Itacolomi. Relatório Técnico (polígrafo). UFOP/BIRD/IEFPROFLORESTA, Ouro Preto. 151p.

Nunes, S.R.D.F.S; Garcia, F.C.P.; Lima, H.C. \& CarvalhoOkano, R.M. 2007. Mimosoideae (Leguminosae) arbóreas do Parque Estadual do Rio Doce, Minas Gerais, Brasil: distribuição geográfica e similaridade florística na floresta atlântica no sudeste do Brasil. Rodriguésia 58: 403-421.

Oliveira-Filho, A.T. \& Fontes, M.A.L. 2000. Patterns of floristic differentiation among Atlantic forests in South-eastern Brazil, and influence of climate. Biotropica 32: 793-810.

Oliveira-Filho, A.T.; Vilelas, E.A.; Gavilanes, M.L. \& Carvalho, D.A. 1994. Comparison of the flora and soils of six areas of Montane Semideciduous Forest in southern Minas Gerais, Brazil. Endinburgh Journal of Botany 51: 355-389.

Pedralli, G.; Freitas, V.L.O.; Meyer, S.T.; Texeira, M.C.B. \& Gonçalves, A.P.S. 1997. Levantamento florístico na Estação Ecológica do Tripuí, Ouro Preto, MG. Acta Botanica Brasilica 11: 191-213.

Peron, M.V. 1989. Listagem preliminar da flora fanerogâmica dos campos rupestres do Parque Estadual do Itacolomi, Ouro Preto/Mariana, MG. Rodriguésia 41: 63-69.

Pirani, J.R.; Mello-Silva, R. \& Giulietti, A.M. 2003. Flora de Grão-Mogol, Minas Gerais, Brasil. Boletim Botânico da Universidade de São Paulo 21: 1-24.

Radford, A.E.; Dickison, W.C.; Massey, J.R. \& Bell, C.R. 1974. Vascular plant systematics. Harper \& Row, New York. 891p.

Ribeiro, J.F. 1998. Cerrado: matas de galeria. EmbrapaCPAC, Planaltina. 164p.

Rolim, L.B. \& Salino, A. 2008. Polypodiaceae Bercht \& J. Presl (Polypodiopsida) no Parque Estadual do Itacolomi, MG, Brasil. Lundiana 9: 83-106.

Rudd, V.E. 1965. The American species of Ormosia (Leguminosae). Contributions from the National Herbarium 32: 278-384.

Silva, A.F. 2000. Floresta atlântica. In: Mendonça, M.P. \& Lins, L.V. (eds.). Lista vermelha das espécies ameaçadas de extinção da Flora de Minas Gerais. Fundação Biodiversitas, Zoo-Botânica, BeloHorizonte. Pp. 45-53. 
Lista de Exsicatas

Assis, L.C.S. 378 (33); Damázio, L. s.n. OUPR 4528 (38); Dias, S.J.L. s.n. OUPR 1347 (31); Kuhlmam, J.G. s.n. VIC 2221 (32); Lima, L.C.P. 206 (36), 209 (39), 211 (22), 212 (11), 214 (29), 216 (39), 226 (20), 227 (35), 230 (13), 232 (7), 233 (23), 234 (11), 235 (7), 239 (3), 244 (15), 247 (26), 248 (14), 252 (29), 254 (15), 256 (17), 264 (24), 267 (18), 272 (11), 275 (3), 280 (31), 281 (10), 282 (29), 283 (6), 289 (11), 291 (39), 292 (5), 296 (17), 303 (12), 305 (5), 319 (1), 321 (4), 322 (12), 323 (2), 328 (35), 329 (6), 331 (9), 333 (7), 341 (21), 344 (24), 347 (26), 350 (5), 353 (24), 355, 357 (10), 358 (20), 362 (37), 363 (3), 364 (4), 365 (8), 370 (32), 376 (23), 378 (29), 379 (25), 382 (14), 383 (15), 386 (30), 387 (38), 388 (28), 391 (19), 392 (2), 394 (6), 395 (13), 396 (36), 398 (34), 399 (34), 401 (37), 402 (28), 404 (31), 408 (33), 409 (27), 410 (16); Lima, H.C. 4054 (19), 4066 (22), 4064 (31); Lopes, M.M.M. 37 (25); Magalhães-Gomes, C.F. s.n. OUPR 4568 (19); Matos, A.V.M. s.n. OUPR 7538 (9); Messias, M.C.T.B. 272 (19), 497 (32); Mota, R.C. 626 (27); Nunes, S.R.D.F.S. 118 (16); Rodrigues, I. M. 47 (34); Roschel, M.B. s.n. OUPR 1328 (10); s.n. OUPR 1439 (20); Silveira, R.G. s.n. VIC 14345 (33); Silveira, F.A. s.n. VIC 7658 (1); Sousa, H.C. 214 (21); Tameirão-Neto, E. 2661 (16); Valente, G. 379 (17), 589 (34); s/coletor VIC 15716 (27) 